\title{
COMMENTS
}

\section{TITLE III AT A CROSSROADS: THE ORDINARY COURSE OF BUSINESS IN THE HOME, THE CONSENT OF CHILDREN, AND PARENTAL WIRETAPPING}

\author{
DAVID J. ANDERMAN†
}

"Of what value are the thoughts, reveries and treasured hoardings of scraps of paper that children find so dear? Only that they may be imparted later to some one worthy of complete confidence. Why not to parents? Only because parents have sometimes forfeited the right by their disregard of privacy." 1

"Teach your children: secret recording, like eavesdropping, is shameful and wrong. Snooping by government and credit bureaus is bad enough; we don't want to become a nation of spies. ${ }^{.2}$

\section{INTRODUCTION}

Title III of the Omnibus Crime Control and Safe Streets Act of $1968^{3}$ was enacted to assure the privacy of all oral and wire communications, and to define the circumstances under which interceptions of such conversations may be authorized. ${ }^{4}$ Its sweeping prohibitions apply to "any person" who intercepts the

† B.A. 1991, University of Pennsylvania; J.D. Candidate 1994, University of Pennsylvania. This Comment was written in conjunction with Professor Seth Kreimer's Privacy and Disclosure seminar. I owe thanks to the Honorable Armand Arabian, Associate Justice of the Supreme Court of California, and to Leonard Swyer for introducing me to this area of the law and for the opportunity to begin to address it. I am indebted as well to my fellow University of Pennsylvania Law Review members (especially Tony, Val, and Sal) for their editorial assistance. Finally, I appreciate the loving help and support of my parents, Sigmund and Susan, my family, and all of my friends.

I dedicate this Comment to my father, not because he is a parental wiretapper, but because he continually inspires me to succeed in the law and in life.

${ }^{1}$ MIRIAM VAN WATERS, PARENTS ON PROBATION 56 (1927).

2 William Safire, Telephone Traps, N.Y. TIMES, Nov. 9, 1992, at A17.

${ }^{3}$ Pub. L. No. 90-351, § 802, 82 Stat. 197, $211-25$, reprinted in 1968 U.S.C.C.A.N. 237, 253 (current version at 18 U.S.C. $\$ \S 2510-2521$ (1988 \& Supp. III 1991)) [hereinafter Title III].

${ }^{4}$ See S. REP. No. 1097, 90th Cong., 2d Sess. 66 (1968), reprinted in 1968 U.S.C.C.A.N. 2112, 2153. 
conversations of others without permission, subjecting most instances of private wiretapping to civil and criminal penalties unless specifically excepted. Though Title III contains no general exceptions for domestic wiretapping, many courts have been unwilling to apply Title III's broad prohibitions to the home. The courts' unease with applying Title III to domestic wiretapping stems, in part, from the fact that private wiretapping often involves wiretapping between family members. ${ }^{5}$ The most common cases involve a husband or wife tapping the telephone of a spouse (often recording all incoming and outgoing calls) in order to discover infidelities. ${ }^{6}$ Many cases, however, involve parents intercepting the telephone conversations of their minor children. ${ }^{7}$ The magnitude

5 "In the private sector, the most prevalent form of illegal eavesdropping occurs in the context of marital or family relations. This includes surveillance by one spouse on another, or between lovers, as well as surveillance of children by their parents." NATIONAL COMM'N FOR THE REVIEW OF FED. \& STATE LAWS RELATINC TO WIRETAPPING AND ELEC. SURVEILLANCE, ELECTRONIC SURVEILLANCE 161 (1976) [hereinafter ELECTRONIC SURVEILLANCE] (the Commission was mandated by $\$ 804$ of the Omnibus Crime Control and Safe Streets Act of 1968).

${ }^{6}$ See id. at 22. Although the Commission found that estimates were difficult because many incidents go unreported, "the major category of illegal eavesdropping appears by far to be marital spying, followed by parental, industrial, political, and illegal police spying." Id. The prevalence of domestic wiretapping has caused an "avalanche of cases arising out of marital disputes." CLIFFORD S. FISHMAN, WIRETAPPING AND EAVESDROPPING § 25.1, at 211 (Supp. 1992). Many of these cases involve rather bizarre situations. The facts of People v. Otto, $831 \mathrm{P.2d} 1178$ (Cal.), cert. denied, 113 S. Ct. 414 (1992), are among the more intriguing-and disturbing-of the interspousal wiretapping cases:

Joe Otto's distrust of his younger wife, Brenda Sue, bordered on the obsessive .... To confirm his suspicions [of infidelity], Joe secretly taperecorded Brenda's telephone calls from the family residence. These recordings captured a conversation between Brenda and her suspected paramour which added a new and horrifying dimension to Joe's fears; the illicit alliance was a reality, but its object was not merely his wealth and marriage, it was his life itself.

Joe's concerns proved to be well founded. Within 48 hours of the recorded conversation, he was found dead-bludgeoned to death in his own home.

Id. at 1179. Joe's creation of the incriminating tape recording was held to be a violation of Title III, the evidence was thrown out, and Brenda Sue's conviction for murder was reversed. See id. at 1195.

7 The issue has been presented to courts in numerous Title III cases, although few have addressed the issue directly. See, e.g., Thompson v. Dulaney, 970 F.2d 744, 746 (10th Cir. 1992) (parent recording conversations between child and estranged spouse); Newcomb v. Ingle, 944 F.2d 1534, 1535 (10th Cir. 1991) (wife recording exhusband's telephone conversation in which he instructed their two children to set fire to wife's home), cert. denied, 112 S. Ct. 903 (1992); Anonymous v. Anonymous, 558 F.2d 677, 678 (2d Cir. 1977) (parent recording conversations between child and 
of the problem is not insignificant. A survey of over 160,000 teenagers revealed that thirty-three percent of them thought their parents rarely respected their privacy, one of their major concerns being eavesdropping on telephone conversations. ${ }^{8}$ In one extreme case, a family in Texas recorded the telephone conversations of their drug-abusing daughter almost continuously for six years, including a four year period of twenty-four hour surveillance. ${ }^{9}$

Though such recordings are almost certainly violations of Title III, ${ }^{10}$ courts deciding both interspousal and parental wiretapping cases often refuse to apply Title III's clear prohibitions to "mere domestic conflicts, ${ }^{n 11}$ citing a lack of congressional intent to extend Title III to the home. ${ }^{12}$ Other courts refuse to create an exception to Title III for domestic wiretapping where Congress has mandated none. This division has been the focus of a nineteen year debate among federal and state judiciaries over the scope of Title III's protection.

The dispute began in 1974 when the Fifth Gircuit decided Simpson $v$. Simpson, ${ }^{13}$ the first in a series of cases that held that Congress did not intend Title III to apply to interspousal wiretapping, ${ }^{14}$ thus spawning the so-called "interspousal exception." In Simpson, a suspicious husband placed a recording device on a household telephone to intercept the "mildly compromising" conversations between his wife and another man. ${ }^{15}$ Following

estranged spouse); Scheib v. Grant, 814 F. Supp. 736, 737 (N.D. Ill. 1993) (father recording conversations between ex-wife and son); Platt v. Platt, 685 F. Supp. 208, 208 (E.D. Mo. 1988) (same), rev'd, 951 F.2d 159 (8th Cir. 1989); Janecka v. Franklin, 684 F. Supp. 24, 25 (S.D.N.Y. 1987) (șame), affd per curiam, 843 F.2d 110 (2d Cir. 1988); State v. Shaw, 404 S.E.2d 887, 888 (N.C. Ct. App.) (mother recording son's drug deal), appeal denied, 407 S.E.2d 548 (1991).

${ }^{8}$ See Jane Norman \& MYRON W. HaRRIS, The PrIVATE LifE of the AMERICAN TEENAGER 33-35 (1981).

${ }^{9}$ See Electronic SURVEILlaNCe, supra note 5, at 161.

${ }^{10}$ See id.

11 Anonymous, 558 F.2d at 679; see also Simpson v. Simpson, 490 F.2d 803, 809 (5th Cir.), cert. denied, 419 U.S. 897 (1974); Newcomb, 944 F.2d at 1536; Lizza v. Lizza, 631 F. Supp. 529, 533 (E.D.N.Y. 1986); London v. London, 420 F. Supp. 944, 946-47 (S.D.N.Y. 1976); Baumrind v. Ewing, 279 S.E.2d 359, 359 (S.C.), cert. denied, 454 U.S. 1092 (1981).

12 Courts find this lack of intent both by reviewing the legislative history of Title III, see infra part I, and by extrapolating an intent to "abjure from deciding a very intimate question of familial relations" from the existence of an exception for the use of extension telephones in the home. Simpson, 490 F.2d at 809.

${ }^{13} \mathrm{Id}$.

14 See id.

15 Id. at 804. 
their divorce, the wife brought an action under Title III. ${ }^{16} \mathrm{Al}-$ though the Simpson court observed at the outset that ${ }^{~}[t]$ he naked language of Title III, by virtue of its inclusiveness, reache[d] this case," $" 17$ a "long, exhaustive, and inconclusive" search of legislative materials ${ }^{18}$ led the court to conclude that "Congress did not intend such a farreaching result, one extending into areas normally left to states, those of the marital home and domestic conflicts. ${ }^{19}$ While a number of courts have followed Simpson, the vast majority of courts $^{20}$ and commentators ${ }^{21}$ have severely criticized Simpson's

${ }^{16}$ See id.

17 Id. at 805 .

$18 \mathrm{Id}$. at 806 .

${ }^{19} \mathrm{Id}$. at 805 .

20 See, e.g., Thompson v. Dulaney, 970 F.2d 744, 748 (10th Cir. 1992); Heggy v. Heggy, 944 F.2d 1537, 1541-42 (10th Cir. 1991), cert. denied, 112 S. Ct. 1514 (1992); Kempf v. Kempf, 868 F.2d 970, 972 (8th Cir. 1989); Platt v. Platt, 951 F.2d 159, 160 (8th Cir. 1989); Pritchard v. Pritchard, 732 F.2d 372, 374 (4th Cir. 1984); United States v. Jones, 542 F.2d 661, 669 (6th Cir. 1976); White v. Weiss, 535 F.2d 1067, 1069-70 (8th Cir. 1976); Walker v. Carter, 820 F. Supp. 1095, 1097 (C.D. Ill. 1993); Nations v. Nations, 670 F. Supp. 1432, 1436 (W.D. Ark. 1987); Flynn v. Flynn, 560 F. Supp. 922, 924-25 (N.D. Ohio 1983); Heyman v. Heyman, 548 F. Supp. 1041, 1045 (N.D. Ill. 1982); Gill v. Willer, 482 F. Supp. 776, 778 (W.D.N.Y. 1980); Kratz v. Kratz, 477 F. Supp. 463, $467-76$ (E.D. Pa. 1979); Ex parte O'Daniel, 515 So. 2d 1250, 1251 (Ala. 1987); People v. Otto, 831 P.2d 1178, 1184-85 (Cal.), cert. denied, 113 S. Ct. 414 (1992); State v. Jock, 404 A.2d 518, 521-22 (Del. Super. Ct. 1979); Markham v. Markham, 272 So. 2d 813, 814 (Fla. 1973); Ransom v. Ransom, 324 S.E.2d 437, 43839 (Ga. 1985); Standiford v. Standiford, 598 A.2d 495, 500 (Md. App. 1991); Stamme v. Stamme 589 S.W.2d 50, 52 (Mo. Ct. App. 1979); M.G. v. J.C., 603 A.2d 990, 993 (N.J. Super. Ct. Ch. Div. 1991); Rickenbaker v. Rickenbaker, 290 S.E.2d 347, 352 (N.C. 1976); State v. Shaw, 404 S.E.2d 887, 889 (N.C. Ct. App. 1991); Pulawski v. Blais, 506 A.2d 76, 77 (R.I. 1986); Turner v. P.V. Int'l Corp., 765 S.W.2d 455, 469 (Tex. Ct. App. 1988).

21 See, e.g., JAMEs G. CARR, The LAW OF EleCtronic SurveillanCe § 3.6, at 3-107 (1992) (stating that courts which are reluctant to hold that interspousal and intrafamilial surveillance is unlawful "disregard the straightforward legislative framework and unambiguous statutory language [of Title III] ${ }^{\eta}$ ); FISHMAN, supra note $6, \$ 25.1(\mathrm{c})$, at 212 (noting that Simpson was wrongly decided and that the "trend is against the Simpson "marital home" exception); William J. Holt, Comment, Interspousal Electronic Surveillance Immunity, 7 U. TOL. L. REV. 185, 203 (1975) ("[T]here was no doubt [in Congress] about the propriety of electronic surveillance in the private sector. Congress intended that such activities should be prohibited entirely."); Asenath Kepler, Comment, Title III and the Classic Triangle: Should the Immunity Doctrine Apply to Interspousal Electronic Surveillance?, 12 CREIGHTON L. REV. 1209, 1228 (1979); Jonathan D. Niemeyer, Comment, All in the Family: Interspousal and Parental Wiretapping Under Title III of the Omnibus Crime Act, 81 KY. L.J. 237, 255 (1992) ('TTitle III's] unequivocal 'blanket prohibition' of private wiretapping must be honored."); Dorian L. Rowe, Comment, Wiretapping and the Modern Marriage: Does Title III Provide a Federal Remedy for Victims of Interspousal Electronic Surveillance?, 91 DICK. L. REV. 855, 872 (1987) (exploring the respective roles Title III and the 
interpretation of the language and legislative history of Title III and its creation of the interspousal exception. ${ }^{22}$ These courts hold that the clear and unambiguous language of Title III prohibits all wiretaps except those specifically enumerated. Interspousal wiretapping is not so enumerated. ${ }^{23}$

Although the recent trend among courts is firmly in favor of applying Title III's prohibitions to interspousal wiretapping, courts have been less eager to apply Title III to a second brand of domestic wiretapping - that by parents of their children's telephone conversations. For example, while one panel in the Tenth Circuit found itself "compelled first and foremost by the clear and unambiguous language of [Title III]" to reject the interspousal exception and the reasoning of Simpson in an interspousal wiretapping case, ${ }^{24}$ another panel, in a decision handed down only a month earlier, refused to apply Title III to parental wiretapping, arguing that interspousal wiretapping is "qualitatively different from a custodial parent tapping a minor child's conversations within the family home. ${ }^{25}$

doctrine of interspousal immunity play in cases of interspousal electronic surveillance); Stephen L. Sapp, Note, Private Interceptions of Wire and Oral Communications Under Title III: Rethinking Congressional Intent, 16 AM. J. CRIM. L. 181, 183 (1989) (analyzing the problem of private interceptions which are subjected to warrantless replaying by the authorities and subsequently used as evidence to prosecute crimes other than wiretapping); Note, Interspousal Electronic Surveillance and Title III, 12 VAL. U. L. REv. 537, 542-46 (1978) (criticizing Simpson); Roslyn A. Lipton, Case Note, 27 BUFF. L. REV. 139, 155 (1978) (arguing that "[a]n exemption for marital disputes is suggested neither by the wording nor the legislative history of Title III"); Recent Decision, Criminal Law-Electronic Surveillance-Neither the Plain Language nor the Legislative History of Title III of the Omnibus Crime Control and Safe Streets Act of 1968 Justifies an Implied Exception for Interspousal Wiretapes [sic]-United States v. Jones, 542 F.2d 661 (6th Cir. 1976), 11 GA. L. REv. 427, 436 (1977).

Only one commentator has suggested that Title III should not be applied to interspousal surveillance, arguing instead that, as the issue involves domestic relations doctrine, there is a "strong presumption" that state law should govern. See Cori D. Stephens, Note, All's Fair: No Remedy Under Title III for Interspousal Surveillance, 57 FORDHAM L. REV. 1035, 1052 (1989).

22 The most vitriolic attack on Simpson is presented in Kratz v. Kratz, 477 F. Supp. 463, 467-76 (E.D. Pa. 1979) which criticizes at length Simpson's "Humpty-Dumpty method of jurisprudence." Id. at 470 (citation omitted). See infra notes 171-80 and accompanying text.

${ }_{23}$ See, e.g., United States v. Jones, 542 F.2d 661, 673 (6th Cir. 1976) ("[T]he plain language of the section and the Act's legislative history compels interpretation of the statute to include interspousal wiretaps").

24 Heggy v. Heggy, 944 F.2d 1537, 1539 (10th Cir. 1991), cert. denied, 112 S. Ct. 1514 (1992).

25 Newcomb v. Ingle, 944 F.2d 1534, 1535-36 (10th Cir. 1991) (citing Simpson for support). Apparently, only one decision has held Title III applicable to parental wiretapping. See State v. Shaw, 404 S.E.2d 887 (N.C. Ct. App.), appeal denied, 407 
What is the reason for this disparity? Title III proscribes the interception of telephone conversations by "any person" who does not fall under exceptions specifically provided for in the Act. ${ }^{26}$ There is no explicit exception for parental wiretapping. ${ }^{27}$ As one court has pointed out, "Title III is not ... an intrusion by the federal government into the law of domestic relations . . . . Title III regulates electronic eavesdropping, not marital relations." ${ }^{28}$ Those who oppose applying Title III to parental wiretapping usually focus on a perceived intrusion by government into an area normally left private and open to parental discretion, namely, childrearing. In order to determine whether such an intrusion is justified, the law often mandates an inquiry into whether the "best interests" of a child will be served by governmental involvement. ${ }^{29}$ Under this standard, the argument for exempting parental wiretapping from the prohibitions of Title III is persuasive only if one assumes that parents act in the best interests of their children when they eavesdrop on their conversations. An analogous argument was raised in support of the interspousal exception and subsequently rejected. ${ }^{30}$ In fact, one could argue that allowing parental wiretap-

\section{S.E.2d $548(1991)$.}

${ }^{26} 18$ U.S.C. $\$ 2511(1)$.

${ }^{27}$ See id. $\$ 2511(2)(\mathrm{a})$-(h) (enumerating the exceptions to Title III). Some courts have argued, however, that $\$ 2510(5)(a)(i)$, which excludes from the definition of "electronic, mechanical, or other device[s]" covered by Title III "any telephone ... used . . . in the ordinary course of . . . business," implies that Congress did not intend Title III to apply to telephones used to record conversations in the home. See, e.g., Simpson, $490 \mathrm{~F} .2 \mathrm{~d}$ at 809 . This so called "extension phone exception" is discussed below. See infra part I.A.

${ }^{28}$ Kratz v. Kratz, 477 F. Supp. 463, 475-76 (E.D. Pa. 1979).

${ }^{29}$ See infra note 130 and accompanying text.

${ }^{30}$ It has been argued in interspousal wiretapping cases that the common law "unity of interest" doctrine exempts husbands and wives from liability under Title III because each spouse is assumed to be acting in the best interests of both. See Kepler, supra note 21 , at 1212 . The interspousal immunity doctrine to Title III, just as the interspousal exception itself, has been all but rejected in the past 10 years in the face of universal criticism. See, for example, M.G. v. J.C., 603 A.2d 990 (N.J. Super. Ct. Ch. Div. 1991), where the court stated:

There is no reason whatsoever to allow spouses to perform non-consensual tortious acts against each other than there is to allow them to perform them against third parties. The right of privacy extends within the confines of the marital home. It is not somehow dissipated into the air upon the taking of marriage vows. Moreover since the instant case ... aris[es] from a taping designed to "prove" marital infidelity, can it be seriously argued that a viable marital home or relationship exists. Rather, as is the norm in cases dealing with estranged spouses living under the same roof, the need for privacy is probably greater than under normal living conditions. A secretive taping 
ping is more harmful than regulating it. Indeed, in many situations governmental intrusion into the family may not merely be justified but required. ${ }^{31}$

Moreover, it is not only the privacy of the person whose conversations are intercepted which is violated, but that of the person on the other end of the line as well. ${ }^{32}$ As Justice Brandeis pointed out over sixty-five years ago:

Whenever a telephone line is tapped, the privacy of the persons at both ends of the line is invaded and all conversations between them upon any subject, and although proper, confidential and privileged, may be overheard. Moreover, the tapping of one man's telephone line involves the tapping of the telephone of every other person whom he may call or who may call him. As a means of espionage, writs of assistance and general warrants are but puny instruments of tyranny and oppression when compared with wiretapping. ${ }^{33}$

This Comment argues that Title III's broad prohibitions on wiretapping should be applied to all instances of domestic wiretapping. Inasmuch as parental and interspousal wiretapping are related analytically and combined jurisprudentially, the first half of this Comment will summarize the origins and criticisms of the interspousal exception and suggest that an exception allowing parental and other domestic wiretapping is equally flawed. Part I analyzes the language and legislative history of Title III, focusing on the "extension phone exception" and the issue of one-party consent. Part II addresses the treatment of Title III by the judiciary, from the

of a spouse's calls under these conditions is an invasion in a most egregious fashion.

Id. at 994-95; see also Burgess v. Burgess, 447 So. 2d 220, 222 (Fla. 1984) ("The arguments generally furthered in support of interspousal tort immunity are not applicable where illegal electronic surveillance is an issue.").

31 See infra note 135 and accompanying text.

32 See United States v. Jones, 542 F.2d 661, 670 (6th Cir. 1976); see also Holt, supra note 21, at 208-09 ("It cannot be overemphasized that the evil of electronic surveillance stems from its capability to invade the privacy of innocent people, as well as the privacy of the targeted spouse.").

33 Olmstead v. United States, 277 U.S. 438, 475-76 (1928) (Brandeis, J., dissenting); see also 114 CONG. REC. 14,713 (1968) (statement of Sen. Brewster) (echoing Justice Brandeis's concerns in the debate on Title III). Justice Brandeis's opinion that wiretapping is a violation of the principles underlying the Fourth Amendment was later adopted by the Court in Berger v. New York, 388 U.S. 41, 6364 (1967) and Katz v. United States, 389 U.S. 347, 359 (1967). See United States v. Jones, 542 F.2d 661, 670 (6th Cir. 1976) (pointing out that Title III was drafted in compliance with Berger and Katz). 
relatively settled decisions on interspousal wiretapping to the incomplete and evolving jurisprudence of parental wiretapping. This Part will summarize the origins and criticisms of the interspousal exception in order to suggest how an exception for allowing parental and other domestic wiretapping is equally flawed. Finally, Part III addresses the theoretical justifications and strategies for applying (or not applying) Title III to children.

\section{Title III: The Words and Their Plain Meaning}

Possibly the simplest aspect of the problem of parental wiretapping is presented by the language of Title III. Title III provides that:

(1) Except as otherwise specifically provided in this chapter any person who-

(a) intentionally intercepts, endeavors to intercept, or procures any other person to intercept or endeavor to intercept, any wire, oral, or electronic communication;

....

shall be [criminally] punished ... or shall be subject to [civil] suit as provided in [this section]. ${ }^{34}$

Title III allows such civil suits to be filed by "any person whose wire, oral, or electronic communication is intercepted, disclosed, or intentionally used." ${ }^{35}$ This language led the Supreme Court to declare that " $[t]$ he purpose of the legislation . . . was effectively to prohibit, on the pain of criminal and civil penalties, all interceptions of oral and wire communications, except those specifically provided for in the Act." 36

Although " $[t]$ he major purpose of Title III is to combat organized crime, ${ }^{n 7}$ the legislative history of Title III abounds with expressions which show that Congress intended to prohibit all

3418 U.S.C. $\$ 2511(1)(a)$. Of the exceptions delineated in $\$ 2511(2)(a)-(h)$, only subsection (d), which excepts interceptions which are authorized by one of the parties to the conversation, is arguably applicable to parental wiretapping. Some parents have argued that their children have impliedly authorized the interception of their conversations, or that parents, as guardians, can consent for children. This argument has not been fleshed out in the jurisprudence. See infra part III.

Title III also has an exclusionary rule: $\$ 2515$ prohibits the use of the contents of intercepted communications "in any trial, hearing, or other proceeding in or before any" federal, state, or other governmental body.

${ }^{35} 18$ U.S.C. \& $2520(a)$.

${ }^{36}$ United States v. Giordano, 416 U.S. 505, 514 (1973) (citation omitted).

${ }^{37}$ S. REP. No. 1097, supra note 4, at 70, reprinted in 1968 U.S.C.C.A.N. at 2157. 
incidences of private wiretapping. ${ }^{38}$ For example, Senator McClellan, a sponsor of one of the bills combined to create Title III $^{39}$ stated:

I understand there are those-and I do not quarrel with themwho just simply abhor the thought of anybody tapping the telephone or any such invasion of privacy.

... [A]s a matter of fact, there is no question ... that a lot of wiretapping goes on where privacy is invaded and the law is completely inadequate to protect the individuals [sic] against that intrusion upon his life. ${ }^{40}$

Congress was also aware that private wiretapping often involved domestic relations. Professor G. Robert Blakey, widely perceived as the author of Title III, ${ }^{41}$ has stated that it was "aimed at corrupt

${ }^{38}$ Senate Report 1097 states that:

Title III has as its dual purpose (1) protecting the privacy of wire and oral communications, and (2) delineating on a uniform basis the circumstances and conditions under which the interception of wire and oral communications may be authorized. To assure the privacy of oral and wire communications, [T]itle III prohibits all wiretapping and electronic surveillance by persons other than duly authorized law enforcement officers . . . .

Virtually all concede that the use of wiretapping or electronic surveillance techniques by private unauthorized hands has little justification where communications are intercepted without the consent of one of the participants.

Id. at 66, 69, reprinted in 1968 U.S.C.C.A.N. at 2153, 2156.

One of the four congressional findings which accompanied the introduction of Title III into law read: "To safeguard the privacy of innocent persons, the interception of wire or oral communications where none of the parties to the communication has consented to the interception should be allowed only when authorized [and supervised] by a court of competent jurisdiction ...." Omnibus Crime Control and Safe Streets Act of 1968, Pub. L. No. 90-351, § 801(d), 82 Stat. $197,211$.

${ }^{39}$ See S. REP. NO. 1097, supra note 4, at 66, reprinted in 1968 U.S.C.C.A.N. at 2153 (discussing the legislative origins of Title III).

${ }^{40}$ Criminal Laws and Procedures: Hearings on S. 2187-2191, 2578 Before the Subcomm. on Criminal Laws and Procedures of the Senate Comm. on the Judiciary, 89th Cong., 2d Sess. 38-39 (1966) (statement of Sen. McClellan, Chairman of the Subcommittee, questioning Nicholas Katzenbach, Attorney General of the United States).

11 See United States v. Jones, 542 F.2d 661, 667 n.10 (6th Cir. 1976) (stating that at least two of the three bills which became Title III were based on Professor Blakey's draft statute); see also PRESIDENT's COMM'N ON LAW ENFORCEMENT AND ADMIN. OF Justice, The Challenge of Crime in a Free Society app. A (1967) (Professor Blakey's proposed statute). The President's Commission concluded that "[a]ll private use of electronic surveillance should be placed under rigid control, or it should be outlawed." Id. at 203. 
cops, commercial espionage, and marital litigation. ${ }^{n 42}$ He was dismayed that an early version of Title III, the Right of Privacy Act of $1967,{ }^{43}$ would not make all private wiretapping illegal:

The widespread use of electronic surveillance techniques in this country by private hands is an abomination. I can find no justification for their use and, thus, I welcome the attempt of the Right of Privacy Act to strike at these practices.

Insofar as the act deals solely with bugging, ... [it] is insufficient or deficient, and it is deficient, I think, for this reason: It is based primarily on the commerce clause, and, as a matter of fact, private bugging in this country can be divided into two broad categories, commercial espionage and marital litigation .... $[\mathrm{M}]$ ost domestic espionage or domestic snooping would not be picked up by this statute simply because in most cases it does not "affect commerce."

...

So the statute, as it is presently drafted, will not reach what I would, perhaps, consider a far more fundamental and objectionable invasion of privacy; that is, an attempt to use electronic equipment in the invasion of privacy of the home and, particularly, the marital relationship. ${ }^{44}$

Though they were probably unfounded, Professor Blakey's concerns regarding the Commerce Clause were noted by Congress, and the final version of Title III included an alternative constitutional justification to ensure the application of Title III's prohibitions to domestic wiretapping. ${ }^{45}$

42 Telephone Interview with G. Robert Blakey, Professor of Law, Notre Dame Law School (Nov. 16, 1992). See also Holt, supra note 21, at $205 \mathrm{n} .85$ ("Title III was intended to mean what it says-no surveillance by third parties without warrant-by cops, spouses, or in business-labor or any other relevant relations." (quoting a letter from Professor Blakey to Holt)).

Professor Blakey later became Reporter of the American Bar Association's Advisory Committee on the Police Function which concluded that: "Except as otherwise expressly permitted, the use of electronic surveillance techniques for the overhearing or recording of wire or oral communications uttered in private without the consent of one of the parties should be expressly prohibited. ... [T] The prohibition should be enforced with appropriate criminal, civil, and evidentiary sanctions." American Bar Assoc. Project on Standards for Criminal Justice, Standards RELATING TO ELECTRONIC SURVEILLANCE $\$ 1.1(\mathrm{~b})$, at 5 (Approved Draft 1971).

43 See Right of Privacy Act of 1967: Hearings on S. 928 Before the Subcomm. on Administrative Practice and Procedure of the Senate Comm. on the Judiciary, 90th Cong., 1st Sess., pt. 1, at 1-4 (1967) (text of the Right of Privacy Act of 1967) [hereinafter Right of Privacy Hearings].

14 Id. at 412-13 (statement of Professor G. Robert Blakey).

${ }^{45}$ Professor Blakey felt that although commercial espionage is obviously regulable 
The senators present at the lengthy debates on the Right of Privacy Act also recognized the problem of domestic wiretapping. Senator Long, chairman of the Senate subcommittee analyzing Title III, stated that

[t]he three large areas of snooping in [the non-governmental] field are (1) industrial, (2) divorce cases, and (3) politics. So far we have heard no real justification for continuance of snooping in these three areas. If any justification exists, we will probably hear about it in the next few weeks as we expect to explore the terrain thoroughly. ${ }^{46}$

Senator Hruska, another sponsor of Title III, was joined by Senators Dirksen, Scott, and Thurmond in stating, "[a] broad prohibition is imposed on private use of electronic surveillance, particularly in domestic relations and industrial espionage situations. ${ }^{n 47}$

Indeed, it becomes obvious from the language of Title III and its legislative history that Congress intended Title III to ban all private wiretapping first, and allow specific exceptions later. The fact that there are no references to exemptions for any form of domestic relations from the prohibitions of Title III in either the

by Title III under the Commerce Clause,

this is not true in the domestic relations investigation, which involves ... a far more objectionable invasion of privacy. It is, of course, one thing to overhear a business secret; it is a wholly different matter, however, to place under surveillance the marital relationship. Electronic surveillance by a private individual in another's bedroom cuts most sharply against the grain.

Id. at 442 (prepared statement of Professor Blakey). Even though Professor Blakey was unsure whether the Right of Privacy Act could be constitutionally applied to domestic wiretapping, he felt that it should be, suggesting that Congress "might be able to outlaw it all ${ }^{n}$ if it prohibited wiretapping under the Due Process Clause of the Fourteenth Amendment. Id. at 413; see S. REP. No. 1097, supra note 4, at 92, reprinted in 1968 U.S.C.C.A.N. at 2180 (explaining congressional intent to avoid constitutional challenge under the Commerce Clause "by a clear statutory specification of an alternative constitutional basis for the prohibition," namely, "the right of privacy... arising under certain provisions of the Bill of Rights and the due process clause of the 14th amendment"). It is unclear how reliance on the Fourteenth Amendment makes Title III applicable to domestic wiretapping, in that the requirements of due process apply only to state action. Insofar as Title III is more comprehensive than the proposed Right of Privacy Act of 1967, however, Professor Blakey's fears are inapplicable to Title III and its prohibitions are legitimate under the Commerce Clause. The telephone system, as used both inside and outside of the home, is a major tool of interstate commerce. See U.S. CONST. art. I, \& 8, cl. 3; United States v. Classic, 313 U.S. 299, 315 (1941) (stating that the regulation of interstate telephone, telegraph, and wireless communications is "concededly within" the scope of congressional power under the Commerce Clause).

${ }^{46}$ Right of Privacy Hearings, supra note 43, pt. 5, at 2261.

${ }^{17}$ S. REP. NO. 1097, supra note 4, reprinted in 1968 U.S.C.C.A.N. at 2274. 
statute or legislative history supports this conclusion. ${ }^{48}$ Indeed, Congress was much more concerned that it was potentially allowing too great an invasion of privacy in its fight against organized crime, ${ }^{49}$ or that its exceptions would be construed in such a

${ }^{48}$ In his treatise on the law of electronic surveillance, Professor James G. Carr observed:

Relatively little congressional attention was directed toward the need to control electronic surveillance by private individuals because the issue presented no controversy. To equate the relative silence on the topic of interspousal eavesdropping with acceptance of the practice is to misinterpret the legislative history. The proposal to allow law enforcement surveillance received more attention because it was and is far more controversial.

CARR, supra note 21, § 3.6, at 3-109 to 3-110. The Sixth Circuit in United States v. Jones, 542 F.2d 661 (6th Cir. 1976), also disputed the inference that the "limited attention given [by Congress] to private electronic surveillance. . . reflected Congress' equivocation on the scope of Title III in the private sector," arguing instead that "[ $t]$ he more plausible explanation is that it was the consensus of Congress that there is 'no justification' for private electronic surveillance, so that debate centered on the more volatile issue of law enforcement surveillance." Id. at 671.

49 See Michael J. Kaplan, Annotation, Construction and Application of Provision of Omnibus Crime Control and Safe Streets Act of 1968 (18 USCS \$ 2520) Authorizing Civil Cause of Action by Person Whose Wire or Oral Communication is Intercepted, Disclosed, or Used in Violation of Act, 25 A.L.R. FED. 759, 763 (1975) (stating that the Supreme Court "has noted that [the enforcement provision of Title III] evidences an overriding congressional concern for the protection of privacy" (citing Gelbard v. United States, 408 U.S. 41 (1972))). See also Holt, supra note 21, at 202 n.81. As Holt points out, a number of Congressmen expressed such concerns during debates on the issue:

I cannot ignore the potential consequences of placing "legalized" wiretapping and eavesdropping in the hands of any Government agency. These are weapons which can be so easily corrupted-if for no other reason than they are so effective in controlling public behavior. Spying on its own citizens has always been one of the most effective tools of a totalitarian government-the object of their use being the destruction of privacy.

114 CONG. REC. 14,482 (1968) (statement of Sen. Long);

What we are asked to do today by title III is to authorize a wholesale invasion of citizens' privacy across the country.

id. at 16,284 (statement of Rep. Kastenmeier);

This provision means that under the cover of a law to control and regulate wiretapping or electronic surveillance, the door has been opened to expand the list of crimes for which taps or bugs could be placed.

This provision is a dangerous invasion of our privacy and our security. Who knows how far it may extend?

id. at 16,287 (statement of Rep. Dow);

Are we naive enough to think that "legalization" of this dirty business will result in fewer abuses[?] On the contrary, if we enact title III . . . as it is presently drafted, I think we will be providing law enforcement officers with a license to do wholesale tapping and bugging. Title III is so full of dangerous loopholes that it could be characterized as a legal fishnet.

id. at 14,713 (statement of Sen. Brewster). 
manner as to allow even some slight degree of private wiretapping. ${ }^{50}$

After twenty years of judicial interpretation of Title III, few courts are willing to argue that the legislative history supports the notion that Congress intended to exempt domestic wiretapping from the prohibitions of the Act. ${ }^{51}$ With regard to parental wiretapping, the courts are therefore forced to rely on two exceptions to Title III to keep it out of the purview of Title III: the extension phone exception, ${ }^{52}$ and the one-party consent exception..$^{53}$

\section{A. The Extension Phone (nee Ordinary Course of Business) Exception}

Perhaps the most common tool of household eavesdroppers is the extension phone. Its use can range from the harmlessly accidental (the phone rings and two people answer), to the outrageously purposeful (an extension phone is installed many miles from home where a voice-activated recorder tapes all incoming and outgoing calls). ${ }^{54}$ While it is doubtful that the first type of eaves-

${ }^{50}$ As the senators argued in the debates:

We have gone to every length which is proper, we think, to protect people's privacy. Today, individual privacy is being promiscuously invaded all over the country. The law is weak. The people who are against this title will talk about invasion of privacy but, privacy is being invaded today all the time. Now they are going a bit further. Today snoopers get hired to install tapes and electronic surveillance devices, and they are getting by with it because we cannot convict now under the present law; because we have to prove not only interception, but use.

....

... This tightens the law on the invasion of privacy. That is the very first thing it does. That is one of its objectives, to correct present law, and at the same time not deny but permit, under the strictest regulation, court ordered supervision, and utilization of this technique for the investigation of crime.

id. at 14,470 (statement of Sen. McClellan);

Not only must we be concerned about the civil liberties aspects of organized crime. Not only must we be concerned that those whom organized crime hurts most are those who most need society's protection. We must also be concerned about the indiscriminate use of electronic devices, which would be ended by title III.

id. at 12,989 (statement of Sen. Tydings).

51 See supra notes 20-21 and accompanying text; see also infra notes $167-80$ and accompanying text.

52 See 18 U.S.C. $\$ 2510(4)-(5)(a)(i)$.

53 See $\$ 2511(2)(d)$.

${ }^{34}$ See Rickenbaker v. Rickenbaker, 226 S.E.2d 347, 348 (N.C. 1976). 
dropping can or should be regulated under Title III, it is likely that Title III prohibits the second.

\section{Defining "Ordinary"}

Title III defines "intercept" as "the aural or other acquisition of the contents of any ... communication through the use of any electronic, mechanical, or other device." 55 Section 2510(5) excludes from the definition of "electronic, mechanical, or other device . . . any telephone . . . furnished to the subscriber or user by a provider of wire or electronic communication service ... and being used by the subscriber or user in the ordinary course of its business. ${ }^{\text {} 56}$ Because many parental and interspousal wiretapping cases involve eavesdropping over an extension phone, courts have been forced to grapple with whether an extension phone is an "electronic, mechanical, or other device," and thus whether the "ordinary course of business" encompasses the use of extension phones in the home. Indeed, courts have made this inquiry so frequently that $\$ 2510(5)(a)$ has come to be referred to as the "Extension Phone Exception" rather than the "Ordinary Course of Business Exception," at least in domestic wiretapping cases. ${ }^{57}$

At first blush, the extension phone exception does not seem to apply to domestic wiretapping. Taken literally, the statute's reference to use "in [the] ordinary course of business" should only apply to commercial activity. ${ }^{58}$ Some courts, however, can find

$55 \S 2510(4)$.

$56 \S 2510(5)$.

57 Like the interspousal exception itself, reference to $\$ 2510(5)(a)(1)$ as the "extension phone exception" probably originated in Simpson v. Simpson. See Simpson, $490 \mathrm{~F} .2 \mathrm{~d}$ at 809 (stating that $\$ 2510(5)(\mathrm{a})(1)$ "directly covers" the use of extension phones in the home); see also People v. Otto, 831 P.2d 1178, 1189 (Cal.), cert. denied, 113 S. Ct. 414 (1992) (stating that the Simpson court "relied on Title III's so-called 'extension phone' exception").

${ }^{58}$ Black's Law Dictionary defines "ordinary course of business" as "[t]he transaction of business according to the common usages and customs of the commercial world generally or of the particular community or (in some cases) of the particular individual whose acts are under consideration." BLACK'S LAW DICTIONARY 1098 (6th ed. 1990). "Business" is generally considered commercial activity, although "[t]hat which habitually busies or occupies or engages the time, attention, labor, and effort of persons as a principal serious concern or interest" can also be one's business. Id. at 198; see also RANDOM HOUSE WeBsTER's COLlege DictionaRY 185 (1991) (stating that the seventh definition of "business" is "something with which a person is rightfully concerned," though the first six are commercial).

One line of cases has applied this logic. In Briggs $v$. American Air Filter Co., the court noted that: 
"no persuasive reason why Congress would exempt a business extension and not one in the home." 59 For those courts, that the extension phone exception applies in the home "is indicative of Congress's intention to abjure from deciding a very intimate question of familial relations." ${ }^{\text {"0 }}$ This translates into the broader, yet flawed, conclusion that Title III does not apply to any domestic wiretapping. ${ }^{61}$

Assuming that the exception for telephones used in the "ordinary course of business" embraces telephones used in the home, it is possible to see how what may be "ordinary" in a business setting is not "ordinary" at home, and vice versa. For example, one might expect calls to be systematically recorded in certain business or business-like situations (perhaps to enhance 911 emergency services or to ensure quality control in a telemarketing business); ${ }^{62}$ in contrast, one would not expect calls to be monitored at random

it is hard to see how use of an extension telephone to intercept a call involving non-business matters could be in the "ordinary course of business," since such activity is unlikely to further any legitimate business interest. However, interception of calls reasonably suspected to involve nonbusiness matters might be justified by an employer who had had difficulty controlling personal use of business equipment through warnings.

630 F.2d 414, 420 n.8 (5th Cir. 1980). Watkins v. L.M. Berry \& Co., 704 F.2d 577 (11th Cir. 1983), added to this analysis, stating that: "[t]his suggests that, if interception of personal calls is permitted at all, it is permitted only for a very limited purpose." Id. at 583 . One judge in Briggs proposed an even simpler analysis: "I think the distinction is reasonably clear as to what can and cannot be intercepted: a business call can be, a private call cannot be." 630 F.2d at 421 (Clark, J., concurring).

${ }^{59}$ Newcomb v. Ingle, 944 F.2d 1534, 1536 (10th Cir. 1991); see also Simpson, 490 F.2d at 809 (" $[\mathrm{I}] \mathrm{t}$ is clear that Congress did not intend to prohibit a person from intercepting a family member's telephone conversations by use of an extension phone in the family home-[the extension phone exception] directly covers this point.").

60 Simpson, 490 F.2d at 809.

${ }^{61}$ See, e.g., Simpson, 490 F.2d at $809 \&$ n.17 (concluding that statements suggesting congressional awareness of the use of electronic surveillance by individuals in their homes does not support the proposition that Congress was concerned that such activities took place); Anonymous v. Anonymous, 558 F.2d 677, 678-79 (2d Cir. 1977) (concluding that the act of listening to one's wife's and daughter's telephone conversations from an extension phone in one's own home would certainly be in the "ordinary course of the user's business") (quoting 18 U.S.C. \$ 2510(5)(a)(i)); Newcomb, 944 F.2d at 1536 n.5 (following Anonymous); Platt v. Platt, 685 F. Supp. 208, 209 (E.D. Mo. 1988) (same), rev'd, 951 F.2d 159 (8th Cir. 1989); Janecka v. Franklin, 684 F. Supp. 24, 26 (S.D.N.Y. 1987) (same).

${ }^{62}$ Seg, e.g., Briggs, 630 F.2d at 420 (holding that the interception of a specific call based on specific fears of disclosure of confidential business information was not part of a systematic attempt to intercept calls, and was therefore made in the ordinary course of business). 
for other, less business-related reasons. ${ }^{63}$ A recent example of the latter situation involved the alleged monitoring of certain phone calls made at the State Department, leading to widespread questions of whether such eavesdropping is legal under Title III. ${ }^{64}$

In the home, it probably would not surprise many people to learn that sometimes one or more of their telephone conversations are casually and unintentionally overheard over an extension phone by someone else. Such intrusions on privacy may be expected and unavoidable, and arguably unpunishable. ${ }^{65}$ The interceptions are ordinary in the sense that they are often accidental. They simply do not fulfill the requirement in Title III that interceptions be intentional. ${ }^{66}$ In the business setting, courts have held such "accidental" interceptions to be in the ordinary course of business, even when the eavesdropping lasted upwards of five minutes. ${ }^{67}$

${ }^{63}$ See infra notes 107-12 and accompanying text.

${ }^{64}$ See Robert Pear, High Bush Official is Linked to Search of File on Clinton, N.Y. TIMEs, Nov. 14, 1992, at 9 ("State Department officials confirmed that the agency's operations had monitored [the official's] telephone conversations with other Administration officials. . . . The [FBI] has opened an inquiry to see if the monitoring violated Federal wiretap statutes.").

${ }^{65}$ Even this basic statement may be untrue, however. Take, for example, a point made by Chief Justice Warren in considering the nature of extension phones:

Common experience tells us that a call to a particular telephone number may cause the bell to ring in more than one ordinarily used instrument. Each party to a telephone conversation takes the risk that the other party may have an extension phone and may allow another to overhear the conversation. When such takes place there has been no violation of any privacy of which the parties may complain.

Rathbun v. United States, 355 U.S. 107, 111 (1957) (emphasis added) (ruling on the legality of extension phone eavesdropping under the less protective precursor to Title III, $\S 605$ of the Federal Communications Act of 1934, Pub. L. No. 73-416, 48 Stat. 1064, 1103-04 (codified as amended at 47 U.S.C. $\$ 605$ (1988))). For a discussion of the differences between Title III and $\$ 605$ of the Federal Communications Act, see United States v. Seidlitz, 589 F.2d 152, 156 (4th Cir. 1978), cert. denied, 441 U.S. 992 (1979); S. REP. NO. 1097, supra note 4, reprinted in 1968 U.S.C.C.A.N. at 2196-97.

The negative implication of Chief Justice Warren's statement is that overhearing a telephone conversation via extension phone without authorization would be an invasion of privacy.

${ }^{66}$ See 18 U.S.C. $\$ 2511(1)(a)$-(b). The level of intent required to violate Title III was lowered from "willful" to "intentional" by amendment in 1986, See Electronic Communications Privacy Act of 1986, Pub. L. No. 99-508, § 101(f)(1), 1986 U.S.C.C.A.N. (100 Stat.) 1848, 1853.

${ }^{67}$ See, e.g., United States v. Axselle, 604 F.2d 1330, 1333-35 (10th Cir. 1979) (finding, before Title III was amended to lower the level of intent to "intentional," that an interception by a motel operator of a guest's conversation for "up to five minutes" was not "willful"). But see Watkins v. L.M. Berry \& Co., 704 F.2d 577, 58485 (11th Cir. 1983) (arguing that although cases which hold short, accidental interceptions exempt from Title III "represent sensible applications of the appropriate 
On the other hand, more systematic interceptions of telephone conversations via extension telephones raise the intrusion on privacy to another level of seriousness, ${ }^{68}$ especially when the eavesdropper uses a tape recorder on a regular basis. This distinction makes intuitive sense. At the most practical level, a recording device is much more difficult to detect than a person listening in. The tape recorder, like an electronic wiretap, does not create noises, does not need sleep, and does not require a constant vigil by the phone. ${ }^{69}$ A person who tapes a conversation, even through the simple means of turning on an answering machine, need not worry about carefully lifting the receiver in order to avoid detection. ${ }^{70}$ On a more substantive level, the act of recording conversations is evidence of a more systematic and determined effort to invade the privacy of the intercepted parties. And while one may be able to characterize

legal standard to specific facts," the holding of Axselle "absolutely contradicts the meaning of the operative language").

${ }^{68}$ Indeed, at least in the business setting, courts are quite suspicious of systematic recording. See, e.g., Watkins, 704 F.2d at 583 ("We hold that a personal call may not be intercepted in the ordinary course of business . . . except to the extent necessary to guard against unauthorized use of the telephone or to determine whether a call is personal or not."); Briggs v. American Air Filter Co., 630 F.2d 414, 420 n.9 ("A general practice of surreptitious monitoring would be more intrusive on employees' privacy than monitoring limited to specific occasions.").

69 One commentator has explained the difference between systematic recording and individual instances of eavesdropping on extension phones:

There are two vital distinctions between an extension phone and a wiretap as they are used to intercept private conversations-the degree of human supervision and the potential product. Extension phone eavesdropping requires the presence of the eavesdropper, and therefore human frailties such as hunger and sleep are limiting factors. Also, as should be obvious, detection is a real problem to the eavesdropper who uses an extension phone. All of this necessarily affects the product that can be realistically derived from this type of surveillance. In contrast, a wiretap depends upon a minimum of human supervision. After installation, only periodic visits might be needed for maintenance, and this, as well as the technical sophistication of a wiretap, dramatically reduces the danger of detection. The product of such a tap, if desired, can reflect all the conversations that occur through the phone at all hours of the day. Therefore, extension phone eavesdropping has much less potential for violating the privacy of the targeted party, and, more importantly, the privacy of innocent third parties, than a wiretap.

Holt, supra note 21, at 205-06.

${ }^{70}$ Detectability has been quite important to courts in determining that recording devices are a clear violation of Title III. See, e.g., Deal v. Spears, 980 F.2d 1153, 1158 (8th Cir. 1992) ("Deal ordinarily would know (by the 'click' on the line) when the residential extension was picked up while she was using the store phone; thus her calls likely would not have been intercepted if the recorder had not been in place."). 
the systematic recording of certain portions of conversations in the workplace as "ordinary," one would be hard pressed to justify as "ordinary" systematic recordings in the home. For example, in United States $v$. Harpel, ${ }^{71}$ a case in which the defendant recorded calls via an extension phone, the court held "as a matter of law that a telephone extension used without authorization or consent to surreptitiously record a private telephone conversation is not used in the ordinary course of business. This conclusion comports with the basic purpose of the statute [and] the protection of privacy. ${ }^{72}$

\section{Applying the Exception}

Though the broad holding of the Harpel court may be morally appealing, ${ }^{73}$ other courts have refused to conclude that instances of surreptitious recording are out of the ordinary, either in the home or in the business environment. ${ }^{74}$ Often, an analysis of what

71493 F.2d 346 (10th Cir. 1974).

72 Id. at 351; see also Gerrard v. Blackman, 401 F. Supp. 1189, 1193 (N.D. Ill. 1975) (stating that the interceptions were surreptitious and not in the ordinary course of business); People v. Otto, 831 P.2d 1178, 1190 (Cal.) ("Whatever Congress might have intended concerning the occasional use of an extension phone by a parent, we find no evidence of a legislative intent to create a wholesale exception for systematic interspousal wiretapping [using a recording device]."), cert. denied, $113 \mathrm{~S}$. Ct. 414 (1992); Rickenbaker v. Rickenbaker, 226 S.E.2d 347, 350 (N.C. 1976) (holding recording via extension phone installed outside the home not in the ordinary course of business); State v. Shaw, 404 S.E.2d 887, 889 (N.C. Ct. App.) (holding use of microcassette recorder to record conversation overheard on an extension line not in the ordinary course of business), appeal denied, 407 S.E.2d 548 (N.C. 1991).

Other courts have held, however, that because it is not illegal to eavesdrop by simply picking up the extension phone and listening, " $t]$ he fact that [the eavesdropper] taped the conversation ... [is] a distinction without a difference." Anonymous v. Anonymous, 558 F.2d 677, 679 (2d Cir. 1977); see also Simpson, 490 F.2d at 809; London v. London, 420 F. Supp. 944, 946 (S.D.N.Y. 1976) (holding that "Congress did not intend to proscribe the recording of calls made or received by a family member over one's own home telephone").

${ }^{73}$ For example, noted columnist William Safire argued in a series of editorials that all nonconsensual recordings of telephone conversations should be prohibited. See William Safire, Foreign Service Scandal, N.Y. TIMES, Nov. 23, 1992, at A17 (" [W]e must end the dirty business of eavesdropping by secretly recording conversations. Step One is to vigorously enforce the law against unwarranted snooping . . . ."); William Safire, Peeping Tom Lives, N.Y. TIMES, Jan. 4, 1993, at A15 ("What can we do to defend ourselves against the relentless penetration of our 'personhood,' in Justice Sandra Day O'Connor's apt word ... ? We can start by teaching each other that eavesdropping ... is all the more wrong now that wearing a wire or planting an FM bug to entrap is so easy."); Safire, supra note 2, at A17 ("Recording another person's conversation, when he or she is speaking with a reasonable expectation of privacy, is ethically repugnant-and in some enlightened states, unlawful.") [hereinafter collectively referred to as Safire Editorials].

74 Briggs, for example, rejected the broad holding of Harpel, arguing that the 
constitutes the ordinary use of extension phones in a business setting could lead to exactly the opposite conclusion to that of ordinary use in the home. For this reason, an ad hoc determination of whether the use of an extension telephone in a particular case was ordinary would seem to be required before one could determine whether Title III had been violated. Nonetheless, courts have been much more conscientious in applying a rigorous "ordinary use" analysis on a case-by-case basis to commercial wiretapping than to domestic wiretapping. ${ }^{75}$ Indeed, courts applying Title III in the business setting have been quite discriminating in observing the differences between personal and business calls, and they have arrived at different outcomes on the basis of express or implied consent to monitor calls, the nature and extent of the invasion, and

Harpel analysis would make the ordinary course of business exception "superfluous." 630 F.2d at 419.

${ }^{75}$ See, e.g., Deal v. Spears, 980 F.2d 1153, 1158 (8th Cir. 1992) (holding 22 hours of recordings made over an extension phone in appellee's business not in the ordinary course of business); Epps v. St. Mary's Hosp., 802 F.2d 412, 416-17 (11th Cir. 1986); Briggs, 630 F.2d at 420 (interception of an individual business call for a specific reason, and not as part of a more systematic monitoring practice, was in the ordinary course of business); Watkins v. L.M. Berry \& Co., 704 F.2d 577, 583 (11th Cir. 1983) (holding, in extending Briggs, that in the business setting, "a personal call may not be intercepted in the ordinary course of business under the [ordinary course of business exception], except to the extent necessary to guard against unauthorized use of the telephone or to determine whether a call is personal or not"); United States v. Paul, 614 F.2d 115, 117 (6th Cir.) (holding monitoring of prison inmates' calls when inmates notified of monitoring within the ordinary course of duty of correctional facility), cert. denied, 446 U.S. 941 (1980); Campiti v. Walonis, 611 F.2d 387, 392 (1st Cir. 1979) (use of an extension phone by police officer to intercept inmate's conversation not in the ordinary course as there is no extension phone exception to Title III); United States v. Axselle, 604 F.2d 1330, 1335 (10th Cir. 1979) (five minute interception of motel guest's conversation by switchboard operator not a violation of Title III because call was originally intercepted pursuant to "the procedure followed at the motel"); James v. Newspaper Agency Corp., 591 F.2d 579, 581 (10th Cir. 1979) (monitoring of employee phone calls by supervisor where employees previously notified falls within the ordinary course exception); Harpel, 493 F.2d at 351 ("We hold as a matter of law that a telephone extension used without authorization or consent to surreptitiously record a private telephone conversation is not used in the ordinary course of business."); Jandak v. Village of Brookfield, 520 F. Supp. 815, 821-25 (N.D. Ill. 1981) (systematic recording of calls to police station done in the ordinary course of police business); Gerrard v. Blackman, 401 F. Supp. 1189, 1193 (N.D. III. 1975) (interception of calls between patient and attorney not done in the ordinary course of business); United States v. Christman, 375 F. Supp. 1354, 1355-56 (N.D. Cal. 1974) (interception of calls over closed circuit, in-house telephone system in the ordinary course of business); United States v. Banks, 374 F. Supp. 321, 326 (D.S.D. 1974) (monitoring of party line for reasons other than legitimate business purposes not in the ordinary course). 
whether the interception of a specific call was in the ordinary course of business, regardless of a general policy to monitor telephones. ${ }^{76}$ Such scrutiny has not been applied to domestic wiretapping. This could be due, in part, to the fact that courts are accustomed to applying the "Extension Phone Exception" as opposed to the "Ordinary Course of Business Exception."77 The use of this shorthand reference may lead courts to pass over an analysis of whether a specific interception in the home was ordinary, relying instead on a factual determination of whether the phone was an extension. Indeed, courts regularly use a standard in the business setting which analyzes how ordinary the eavesdropping was, ${ }^{78}$ while rejecting the same approach in considering the home. ${ }^{79}$

${ }^{76}$ See Watkins, 704 F.2d at 581-85 (discussing each of these elements).

${ }^{77}$ See supra note 57 and accompanying text. This difference in terminology may not be lost on all courts, however. See, e.g., Deal v. Spears, 980 F.2d 1153, 1159 (8th Cir. 1992) (referring to the "telephone extension/business use exemption of Title III"); Briggs, 630 F.2d at 419 (referring, for the most part, to the "ordinary course of business' exception").

${ }^{78}$ See, e.g., Campiti, 611 F.2d at 392 (use of an extension phone by prison guards to overhear inmate's conversation not "in the ordinary course of business" and therefore invalid under Title III); Harpel, $493 \mathrm{~F} .2 \mathrm{~d}$ at 351 (stating that unauthorized interception, recording, and disclosure of a conversation between two law enforcement officials was not "in the ordinary course of business" and holding "as a matter of law" that no recording made via extension telephone could be made "in the ordinary course of business"); Briggs v. American Air Filter Co., 455 F. Supp. 179, 181 (N.D. Ga. 1978) (accepting Harpel but holding that an employer who intercepted certain conversations of his employee via extension phone did so "in the ordinary course of business" because he listened to protect the interests of the company and not for personal reasons), aff'd, 630 F.2d 414 (5th Cir. 1980); Gerrard v. Blackman, 401 F. Supp. 1189, 1193 (N.D. Ill. 1975) (surreptitious interceptions of conversations between a mental patient and her attorney are "not in the ordinary course of business unless defendants can establish that it is their ordinary course of business to intercept conversations between patients and their counsel, a practice which would not be justified even if customary"); United States v. Christman, 375 F. Supp. 1354, 1356 (N.D. Cal. 1974) (holding interception via an extension telephone attached to a closed-circuit, in-store telephone system not a violation of Title III); United States v. Sturdivant, 9 M.J. 923, 924-25 (A.C.M.R. 1980) (extension phone used by sergeant to intercept soldier's conversations was used "in the ordinary course of business," and soldiers had no "reasonable expectation of privacy" (suggesting a reliance on Katz)), rev'd, 13 M.J. 323 (C.M.A. 1982).

${ }^{79}$ In the realm of domestic wiretapping, courts generally have not analyzed specific instances of interceptions to determine if they were ordinary, but instead have relied on the general assumption that there is an exception for extension telephones used in the home, even when a recording device is attached to the extension phone. See, e.g., Anonymous v. Anonymous, 558 F.2d 677, 679 (2d Cir. 1977); Simpson, 490 F.2d at 809; London v. London, 420 F. Supp. 944, 946 (S.D.N.Y. 1976). But see People v. Otto, 831 P.2d 1178, 1190 (Cal.), cert. denied, 113 S. Ct. 414 (1992); Rickenbaker v. Rickenbaker, 226 S.E.2d 347, 350 (N.C. 1976); State v. Shaw, 404 S.E.2d 887, 889 (N.C. App.), appeal denied, 407 S.E.2d 548 (1991). 
Beyond its origins as a simple nickname, this approach, though inconsistent and illogical, seems to stem from a rather isolated statement made during the legislative hearings on Title III.

Professor Herman Schwartz, one witness at a 1967 House of Representatives hearing on the problem of wiretapping, has been cited in many cases ${ }^{80}$ as saying, "I take it nobody wants to make it a crime for a father to listen in on his teenage daughter or some such related problem. I do not know. ${ }^{n 1}$ To these courts, Professor Schwartz's statement shows Congress's “clear" intent to allow interceptions by family members within the home. ${ }^{82}$ While some courts and commentators have attempted to downplay Professor Schwartz's statement by pointing out that it was uttered by a witness and not by a senator, ${ }^{83}$ and that it was unique in the legislative history, ${ }^{84}$ taken in context the quote has a simpler explanation. The draft wiretapping bill Professor Schwartz commented on contained an extension phone exception worded quite broadly, exempting " an[y] extension telephone furnished to the subscriber or user by a communications common carrier. ${ }^{\text {85 }}$ In his statement prepared on behalf of the American Civil Liberties Union, Professor Schwartz observed that the exception, as written in the bill,

means that the law does not prohibit any eavesdropping whatsoever, if performed by means of an extension telephone. We are somewhat at a loss to understand why so broad an exclusion is created .... Perhaps there is no need or desire to regulate the situation where the head of a family listens in on a conversation between his teen-age daughter and her boyfriend, or to find out if someone is using the phone without authority. Perhaps. But by

${ }^{80}$ See, e.g., Newcomb v. Ingle, 944 F.2d 1534, 1536 n.5 (10th Cir. 1991); Anonymous, 558 F.2d at 679; Simpson, 490 F.2d at 809 \& n.17; Platt v. Platt, 685 F. Supp. 208, 209 (E.D. Mo. 1988), rev'd, 951 F.2d 159 (8th Cir. 1989).

81 Hearings on the Anti-Crime Program Before Subcomm. No. 5 of the House Comm. on the Judiciary, 90th Cong., 1st Sess. 989 (1967) [hereinafter Hearings on the Anti-Crime Program] (testimony of Professor Schwartz).

82 The origin of this position is generally credited to Simpson. See supra note 57.

83 See, e.g., Lipton, supra note 21, at 149 ("There is no evidence that any member of Congress ever acknowledged that one of the purposes of the extension phone exception was to allow a father to eavesdrop on his teenage daughter.").

8 See, e.g., Kratz v. Kratz, 477 F. Supp. 463, 474 (E.D. Pa. 1979) (commenting, in evaluating the effect of Professor Schwartz's statement on the interspousal exception, that "[w] hatever Congress thought about the legal rights of minor children vis-a-vis their parents, this isolated statement by a witness at a congressional hearing certainly does not warrant the conclusion that Congress viewed husbands and wives as less than full equals before the law").

85 H.R. 5386, 90th Cong., 1st Sess. § 2515(d)(1) (1967). 
defining "interception" as always excluding use of an extension phone, the following situations are also excluded from regulation:

(1) an eavesdropper breaks in, hides in one part of the house or office without the knowledge of anyone else, and listens in on an extension;

(2) the police or someone else coerce someone into letting them listen in on an extension phone;

(3) the police or someone else obtain authority to listen in on an extension phone by someone not a party to the conversation and who has no authority of any kind to allow them to do so.

Surely, eavesdropping should be allowed in one of these cases, but because of the blanket exemption for extension phones, they are completely exempt from regulation. We would therefore recommend deletion of [the exception] or at least some kind of redefinition limiting it to the specific types of cases the draftsmen had in mind. ${ }^{86}$

As his statement shows, Professor Schwartz's concern was not that the use of extension phones to eavesdrop would be made illegal, but that it would exempt too many situations he considered objectionable. The draftsmen apparently took heed of his concerns, because they added the "ordinary course of . . . business" language to qualify the exception, and removed the explicit reference to extension telephones. ${ }^{87}$ Rather than implying that Congress ought to ignore the situation involving parental tapping of children's phones, Professor Schwartz's statement implicitly calls for an evaluation of each situation-be it in the commercial or domestic setting-to determine the desirability of allowing an exception to the general prohibitions of Title III. Only in this way does the ordinary course of business exception make sense.

\section{Getting Down to Business}

Requiring courts to apply the ordinary course of business exception evenly in both commercial and domestic wiretapping cases is neither an impossible nor unprincipled approach to statutory construction, nor does it place an unreasonable strain on

${ }^{86}$ Hearings on the Anti-Crime Program, supra note 81, at 1014-15 (prepared statement of Professor Schwartz). Professor Schwartz's testimony closely follows the wording and organization of his prepared statement. Compare id. at 950-91 (testimony of Professor Schwartz) with id. at 1008-17 (prepared statement of Professor Schwartz).

8718 U.S.C. $\S 2510(5)(a)(i)$. 
a court system already burdened by "an avalanche ${ }^{n 88}$ of such cases. A similar analytical framework is presented in Katz $v$. United States, ${ }^{89}$ upon which Title III is based. ${ }^{90} \mathrm{Katz}$, which involved the interception by government agents of telephone conversations made at a public telephone, mandates an analysis of the reasonable expectations of privacy of a party whose conversations are intercepted via electronic eavesdropping. ${ }^{91}$ The Katz Court rejected the long-standing "trespass doctrine" enunciated in Olmstead $v$. United States, ${ }^{92}$ which held that wiretapping does not constitute an unreasonable search and seizure under the Fourth Amendment because a wiretap is not a search of any constitutionally protected area nor a seizure of anything tangible. ${ }^{93}$ Instead, Katz held that "[o]ne who occupies [a telephone booth], shuts the door behind him, and pays the toll that permits him to place a call is surely entitled to assume that the words he utters into the mouthpiece will not be broadcast to the world, ${ }^{n 4}$ and, more fundamentally, that "the Fourth Amendment protects people, not places."

Title III analysis should invoke the reasoning employed in Katz by recognizing the distinction between a right to privacy which applies to a particular location or form of communication and a right to privacy based on a person's legitimate expectations in a given situation. ${ }^{96}$ Title III already invokes the Katz analysis

88 See supra note 6.

89389 U.S. 347 (1967).

90 See S. REP. NO. 1097, supra note 4, at 66, reprinted in 1968 U.S.C.C.A.N. at 2153.

91 Katz, 389 U.S. at 361 (Harlan, J., concurring).

92277 U.S. 438 (1928).

93 See id. at 464-66.

${ }^{94} \mathrm{Katz}, 389$ U.S. at 352.

95 Id. at 351.

96 One court has implicitly adopted this analysis, holding:

We have been unable to divine any reason for an "extension telephone"

exception. The purpose of the statute is to prohibit the secret monitoring of wire communications. Its application should not turn on the type of equipment that is used, but whether the privacy of telephone conversations has been invaded in a manner offensive to the words and intent of the Act. Campiti v. Walonis, 611 F.2d 387, 392 (1st Cir. 1979).

This approach has met with some criticism. For example, Professor Blakey has said, without elaborating, that "Campiti $v$. Walonis was wrongly decided on every point." Telephone Interview with G. Robert Blakey, Professor of Law, Notre Dame Law School (Nov. 16, 1992). Professor Carr suggests another, closely analogous method for determining what is "ordinary." He argues that Title III "requires that both the installation and use of the instrument be normal." CARR, supra note 21, \$ 3.2(d)(1), at 3-42 (emphasis added). Professor Carr believes that: 
directly by defining "oral communication" as a communication "uttered by a person exhibiting an expectation that such communication is not subject to interception under circumstances justifying such expectation." Title III's definition of "wire communication," by contrast, contains no such requirement. ${ }^{98}$ Although some courts have used this difference to reject any reference to reasonable expectations of privacy, ${ }^{99}$ the Supreme Court's analysis is instructive for, if not dispositive of, an ad hoc analysis of the ordinary course of business exception. This is not to say that the Katz analysis should be substituted for an ordinary course of business analysis. To do so would be, in the words of one court, to "put[] the cart before the horse," 100 as an individual's reasonable expectation of privacy is only enforceable if federal law makes the interception illegal. ${ }^{101}$ Assuming that an individual pursuing a Title III action has no other basis under federal law for having an expectation of privacy, that individual will first have to show that the interception was not in the ordinary course of business. Nonetheless, as the Briggs court observes,

noting that the "ordinary course of business" determination is logically prior to the conclusion that federal law creates an enforceable expectation of privacy ... by no means ... suggest[s] that the same common experience and behavior which help define our expectations are irrelevant to the "ordinary course of business" issue. If the common experience in this country is that under certain circumstances, communications made on office

Reliance on the "normal use" exception of $\$ 2510(5)(a)(i)$ to allow an eavesdropper to use an extension telephone . . . reflects a misunderstanding of the purpose of Title III and a failure to strictly construe its regulatory structure. The tendency to accept an "extension phone" exemption to the statute's prohibition of all forms and modes of electronic eavesdropping would, if implemented, leave the most common means of listening to another's conversations completely unregulated. Instead of embracing the extension phone exemption, courts should carefully distinguish between a use which may be justifiably viewed as normal (i.e., an anxious parent's understandable overhearing of a drug abusing child's conversations), and those which cannot so easily be accepted and tolerated in a society which values and seeks to protect conversational privacy.

Id. § 3.6, at 3-110.2 to 3-110.3 (citations omitted).

9718 U.S.C. $\$ 2510(2)$.

98 See $\$ 2510(1)$.

${ }^{99}$ See, e.g., Kratz v. Kratz, 477 F. Supp. 463, $472-73$ (E.D. Pa. 1979) (holding a determination of the victim's justifiable expectation of privacy irrelevant as a grounds for dismissing a Title III action).

${ }^{100}$ Briggs v. American Air Filter Co., 630 F.2d 414, 417 (5th Cir. 1980).

101 See id. 
telephones are not listened to by employers or their agents, it could not be said that an act of listening to such a conversation is in the "ordinary course of business." 102

An application of Title III which turns solely on the use of particular equipment installed in a particular location (namely an extension phone), without taking into account the circumstances in which the interception takes place, is, by this analysis, misplaced.

A preferable approach would be to factor in expectations of privacy by rigorous application of the ordinary course of business test in both commercial and domestic wiretapping cases. ${ }^{103}$ This approach is much more beneficial than an across the board validation of extension phone interceptions, especially in the home, as each individual's situation can be analyzed separately. More importantly, a flexible standard which factors in expectations of privacy allows courts to determine whether particular methods of interception are prohibited by Title III. Take, for example, the case of a child who has a known drug problem, the archetypical case from whence a justification for parental supervision could spring. ${ }^{104}$ If the parent takes an active role in ensuring that her child is free from drugs, say by enforcing a curfew, taking the child to counseling, and looking for obvious signs of drug use, then the child can expect her parent to monitor her calls to a degree to ensure her safety. In this situation, monitoring could very well be considered to be in the ordinary course of business. ${ }^{105}$ On the other hand, four years of twenty-four hour-a-day surveillance would probably be unreasonable to expect. ${ }^{106}$ A flexible, Katz-like analysis of instances of parental wiretapping would provide a much greater degree of privacy than is currently afforded in the home,

102 Id. at $417-18$.

${ }^{103}$ This view comports with the wishes of Professor Blakey, the drafter of Title III. When asked whether the framers of Title III intended the extension phone exception to apply to the home, Professor Blakey said "It absolutely applies to the home. I wish we had used a different word than 'business' so it wouldn't be limited to commercial phones." Telephone Interview with G. Robert Blakey, Professor of Law, Notre Dame Law School (Nov. 16, 1992).

104 See supra note 96.

${ }^{105}$ See supra note 96 and accompanying text. Even if monitoring is legal, recordings made via extension phones should not be, following the reasoning of United States $v$. Harpel and State v. Shaw. See supra notes 68-72 and accompanying text.

106 See ELECTRONIC SURVEILLANCE, supra note 5, at 161 (relating the story of a sixyear period of surveillance, including a four-year stretch of 24-hour monitoring, by parents of their drug-abusing daughter and describing this incident as a "clear violation of Title III"). 
while allowing reasonable exceptions for situations involving "understandable" attempts by parents to supervise their children.

Though this approach is novel in its application to domestic wiretapping, the application of a Katz-like analysis to the ordinary course of business standard is well-established outside the domestic setting. Watkins v. L.M. Berry $\mathcal{E}^{2} \mathrm{Co}^{107}$ is an excellent example. In Watkins, the employer had a general policy of monitoring sales calls via a normal extension phone. The employees were told that they could make personal calls which the supervisor would monitor only as long as necessary to determine that the calls were not business-related. ${ }^{108}$ During lunch one day, Watkins, an employee of L.M. Berry, received a call from a friend who asked her about a job interview she had had the previous evening with another company. ${ }^{109}$ The call was monitored, and as a result, Watkins was fired the next day. ${ }^{110}$ The Eleventh Circuit argued that to prevail under the ordinary course of business exception, an employer

must show that the interception of the call beyond the initial period was in the ordinary course of business. It is not enough for the Berry Co. to claim that its general policy is justifiable as part of the ordinary course of business. We have no doubt that it is. The question before us, rather, is whether the interception of this call was in the ordinary course of business. ${ }^{111}$

The court held that the answer to the question was a triable issue of fact, and remanded to the district court. ${ }^{112}$ A similar type of percall analysis should be applied across the spectrum of private wiretapping.

In light of the relative clarity and uniformity of decisions which apply the ordinary course of business exception in the business setting, it seems strange that domestic wiretapping decisions have thus far failed to follow the same path. Perhaps the explanation

107704 F.2d 577 (11th Cir. 1983).

108 See id. at 579.

${ }^{109}$ See id.

110 See id. Watkins was called into her supervisor's office and told that the company did not want her to leave. When she asked whether she was being fired, she was told about the interception of her call. Tempers flared and Watkins was fired. She complained to her supervisor's boss and the boss had Watkins reinstated. Within a week, Watkins left L.M. Berry to go to the employer she had interviewed with the night before the interception of her call. See $i d$.

${ }^{111}$ Id. at 582 (emphasis added) (citations omitted). The court went on to note that '[ $t]$ he phrase 'in the ordinary course of business' cannot be expanded to mean anything that interests a company." Id.

112 See id. at 585. 
relates to the "squeamishness" federal courts exhibit when dealing with domestic relations. For example, in the recent case of Shaver $v$. Shaver, ${ }^{113}$ the court devoted an entire section of its opinion to its reservations about hearing a Title III case involving interspousal wiretapping, stating that:

As a general rule, federal courts do not become involved with domestic relations disputes. The court would prefer to adhere to the general rule at the present time, but it is unable to do so. The Fourth Circuit Court of Appeals has declared that [Title III] and the civil action which it creates are intended to reach domestic relations cases. Therefore, the court must rule on the claims presented by plaintiff. ${ }^{114}$

The squeamishness problem is at the center of an historical debate regarding parental authority between those who favor adultlike rights for children versus those who favor a quasi-constitutional right to parental autonomy. This debate, discussed below, ${ }^{115}$ may provide a basis for distinguishing domestic wiretapping from other

113799 F. Supp. 576 (E.D.N.C. 1992).

114 Id. at 577 (citations omitted); see also Pritchard v. Pritchard, 732 F.2d 372, 374 (4th Cir. 1984) (noting that state courts are better suited to handle domestic conflicts, but nonetheless holding that Title III encompasses interspousal surveillance). But see Kratz v. Kratz, 477 F. Supp. 463, 476 (E.D. Pa. 1979):

Our case is a simple one; we deal here only with a fundamental and cherished human right, that of privacy. The enjoyment of that right has been seriously imperiled by modern technology, prompting Congress to enact Title III as a barrier to further encroachment on such enjoyment. Since the right of privacy has been afforded federal statutory protection, there is no justification for a federal court, presented with an "interspousal" Title III suit, to dismiss that suit by stating that it involves only a "domestic conflict."

Id.

Notwithstanding most courts' squeamishness, a recent Supreme Court decision may reflect a trend among courts to loosen the strictures of the domestic relations exception and pave the way for increased federal involvement in domestic disputes. In Ankenbrandt v. Richards, 112 S. Ct. 2206, 2213 (1992), the Court reaffirmed the domestic relations exception to federal diversity jurisdiction on the basis of a century and a half of judicial decisions made with congressional acceptance. Nonetheless, the Ankenbrandt Court expressly held that the domestic relations exception exists as a matter of statutory construction, and is not constitutionally mandated by Article III. See id. at 2210-11. Cf. Barber v. Barber, 62 U.S. (21 How.) 582, 591 (1858) (establishing the domestic relations exception as an extension of the judicial power granted in Article III). In doing so, the Court may have created the possibility of discretionary jurisdiction over domestic relations cases in the federal courts. See Ankenbrandt, $112 \mathrm{~S}$. Ct. at 2217 (Blackmun, J., concurring in the judgment).

${ }^{115}$ See infra part III. 
situations despite the lack of support for such a distinction in Title III.

\section{B. The Issue of One-Party Consent}

Another issue raised in parental wiretapping cases is Title III's exception for consensual interceptions. Section 2511(2)(d) exempts from liability any person who intercepts a communication "where such person is a party to the communication or where one of the parties to the communication has given prior consent to such interception."116 In most situations, determining whether consent has been given is rather straightforward: either it has or it has not. In situations involving children, however, determining the existence of consent can be more difficult, as a parent may be able to consent on behalf of the child if the parent is acting in the child's "best interests."

Although courts interpreting the exception have read "consent" rather broadly, exempting consensual interceptions made for almost any reason, ${ }^{117}$ the legislative history of $\S 2511(2)(d)$ suggests a narrower exception. Senator Hart, sponsor of the one-party consent exception, proposed "to prohibit a one-party consent tap, except for law enforcement officials, and for private persons who act in a defensive fashion."118 Senator Hart gave the situation in which "the party acts out of a legitimate desire to protect himself and his own conversations from later distortions or other unlawful or injurious uses by the other party ${ }^{119}$ as an example of a legitimate consensual tap.

Despite this legislative history, some parents have argued that their interception of their children's conversations does not violate Title III, noting that because wiretapping was in the children's "best interest," the children constructively consented to it. ${ }^{120}$ Although

11618 U.S.C. $\$ 2511(2)(d)$ (1988).

${ }^{117}$ Most commonly, one-party consent is used as a defense by informers who monitor or wiretap for law enforcement purposes. See Clifford S. Fishman, The Interception of Communications Without a Court Order: Tille III, Consent, and the Expectation of Privacy, 51 ST. JoHN's L. REv. 41, 78 (1976) ("When the consenting participant [to an intercepted conversation] is an undercover police officer, a paid informant, a crime victim seeking redress or protection, or a public-spirited citizen, a finding of voluntary consent is almost automatic.").

118114 CONG. REC. 14,694 (1968) (statement of Sen. Hart). One commentator has suggested, without elaboration, that Senator Hart's statement "is inconsistent in tone with the provision itself." FISHMAN, supra note 6, § 25.4, at 225.

119 Id.

${ }^{120}$ See Thompson v. Dulaney, 970 F.2d 744, 749 (10th Cir. 1992) (reversing and 
this argument has not been fully explored by the courts, ${ }^{121}$ it is clear that the issue will have to be addressed.

The issue of consent is not unique to parental wiretapping cases. ${ }^{122}$ Besides cases involving informants in the context of law enforcement, ${ }^{123}$ the consent exception is raised most frequently in the business setting, where it is argued that employees consent to monitoring and recording through actual or implied consent. ${ }^{124}$ As in the debate over extension phones, the issue of consent has been much more rigorously addressed this setting than in the home, and indeed, courts have held businesses to a rather strict standard of consent. ${ }^{125}$ For example, in Watkins v. L.M. Berry $\mathcal{E}$ Co., ${ }^{126}$ the court held that mere acceptance of employment "with knowledge of [a] monitoring policy" did not create actual or implied consent to all interceptions:

It is clear, to start with, that Watkins did not actually consent to interception of this particular call. Furthermore, she did not consent to a policy of general monitoring. She consented to a policy of monitoring sales calls but not personal calls. This consent included the inadvertent interception of a personal call, but only for as long as necessary to determine the nature of the call ....

Consent under title III is not to be cavalierly implied. Title III expresses a strong purpose to protect individual privacy by strictly limiting the occasions on which interception may lawfully take

remanding to the district court for determination of whether parent can give constructive consent for wiretapping); Platt v. Platt, 951 F.2d 159, 161 (8th Cir. 1989) (same); Anonymous v. Anonymous, 558 F.2d 677, 679-80 (2d Cir. 1977) (failing to reach this argument although it was made by the parent); Janecka v. Franklin, $684 \mathrm{~F}$. Supp. 24, 26 (S.D.N.Y. 1987) (relying on Anonymous and Simpson to reject this claim).

121 The cases cited supra note 120 were decided on the grounds that Title III does not apply to domestic wiretapping at all; therefore, they did not reach the issue of whether the child impliedly consented to the tapping.

122 The issues surrounding a child's capacity to consent and whether a parent can consent for his or her child come up in many areas of the law, including medical care, child custody hearings, delinquency proceedings, and education. See generally CHILDREN's COMPETENCE To CONSENT (Gary B. Melton et al. eds., 1983) (addressing issues surrounding children's capacity to engage in complex decision making).

123 See supra note 117.

124 See FISHMAN, supra note $6, \S 25.2$, at 218 (stating that the argument that employees explicitly or implicitly consented to monitoring is a potential defense to the application of Title III to employers).

125 Each of the cases cited supra note 75 contains a discussion of the effect of employee consent on the wiretapping or monitoring at issue, whereas few if any cases in the domestic setting discuss the effect of consent on wiretapping in that context. See supra note 120.

126704 F.2d 577 (11th Cir. 1983). 
place .... It would thwart this policy if consent could routinely be implied from circumstances. ${ }^{127}$

Courts have limited findings of implied consent in the business setting to very narrow circumstances, where it was abundantly clear that the victim of the interception should have known that the phone was being monitored. ${ }^{128}$ The same is not true of the application of the consent exception to parental wiretapping.

Arguing that children consent to having their conversations intercepted implies that children not only can, but wish to give up their right to privacy to the interests of their parents. In a generally harmonious family, such presumptions may have their place. ${ }^{129}$ Indeed, in the present state of the law, analyses of the "best interests" of the child begin from this presumption:

In the eyes of the law, to be a child is to be at risk, dependent, and without capacity or authority to decide free of parental control what is "best" for oneself. To be an adult is in law perceived as free to take risks, with the independent capacity and authority to decide what is "best" for oneself and without regard to parental wishes. To be an adult who is a parent is therefore to be presumed by law to have the capacity, authority, and responsibility

${ }^{127} I d$. at 581 (citation omitted).

128 See, e.g., Jandak v. Village of Brookfield, 520 F. Supp. 815, 824-25 (N.D. Ill. 1981) (holding that "in the unusual circumstances of this case," the police officer should have known that phone lines were continuously monitored for proper police purposes and therefore consented); Simmons v. Southwestern Bell Tel. Co., 452 F. Supp. 392, 396 (W.D. Okla. 1978) (concluding that plaintiff knew that calls made on a business phone were regularly monitored because he had been warned not to use the phone for personal calls and was provided with an unmonitored phone), affd, 611 F.2d 342 (10th Cir. 1979).

129 See LaUrence H. Tribe, american Constitutional Law 1590 n.8 (2d ed. 1988) (arguing that "routine cases of parental discipline in an essentially successful family whose continuation is mutually desired will properly be treated as raising no real constitutional issue, " but will raise an issue if the family is in disarray). Others argue that even in an intact family, conflicts of interest can undermine the justification for "substituting" the judgment of the parent for that of the child:

The concept of substituted judgment [in which an adult provides a kind of proxy consent] presumes a great deal. Most notably, it assumes that the person making the decision is willing and able to act in this capacity on the child's best interests (i.e., without a conflict of interests). Even within the loving, intact, two-parent family, not all parental decisions regarding children are without conflicts of interest. Parents often subordinate their needs and preferences to the best interests of their children (or to what they believe to be their children's best interests), but this is not always the case.

Gerald P. Koocher, Children Under Law: The Paradigm of Consent, in REFORMINC THE LAW 3, 14 (Gary B. Melton ed., 1987) (citation omitted). 
to determine and to do what is "good" for one's children, what is "best" for the entire family. ${ }^{130}$

The law assumes, from the very moment a baby is "assigned" to her natural parents, that the parents will provide the child with the proper environment and strive to serve her best interests. ${ }^{131}$ In the majority of parental wiretapping cases reported, however, the family unit has fallen apart or seems to be deteriorating. ${ }^{132}$ Indeed, in only one of the cases involving parental wiretapping ${ }^{133}$ were the parents of the child not divorced or seeking a divorce. The interceptions were not effected for the interests of the child, but to give the parent leverage in the settlement of custody battles. ${ }^{134}$

Given this situation, determining what is "best" for a child is a dubious proposition. When society has determined that a particular activity is universally wrong, the presumption that parents so acting are doing so in the "best interest" of the child is doubly suspect.

${ }^{130}$ JOSEPH GOLDSTEIN ET AL., BEFORE THE BEST INTERESTS OF THE CHILD 7 (1979) (endnote omitted).

131 Some argue that it is fallacious to assume that the best interests of parents and children are always aligned. For example, Hillary Rodham Clinton has stated:

the presumption of identity of interests between parents and their children should be rejected whenever the child has interests demonstrably independent of those of his parents (as determined by the consequences to both of the action in question), and a competent child should be permitted to assert his or her own interests.

Hillary Rodham, Children Under the Law, 43 HARv. EDUC. REv. 487, 507 (1973).

Others argue that children's rights should be presumptively equal to those of adults: "There must be strong justification for any impairment for [children's] legal rights and for the imposition of any disabilities or incapacities [under the law]. It is naive to assume that rules derived from feudal times are actually protective and serve the best interests of modern children." HENRY H. FOSTER, JR., A "BILL OF RIGHTs" FOR CHILDREN 60 (1974). For a fuller discussion of this debate, see infra part III.

${ }^{132}$ See supra note 7. For a discussion of the status of the homes involved in Title III actions, see generally Christopher J. Sternberg, Note, Interspousal Wiretapping: Defining "Marital Home" for Purposes of Civil Recovery Under Title III, 28 J. FAM. L. 771 (1989).

${ }^{133}$ See State v. Shaw, 404 S.E.2d 887 (N.C. Ct. App.), appeal denied, 407 S.E.2d 548 (N.C. 1991).

${ }^{134}$ See Koocher, supra note 129, at 14 (arguing that conflicts of interests between parent and child could negative the inference that the parent is acting in the best interests of the child). Cf. DePlanche v. Califano, 549 F. Supp. 685, 702 (W.D. Mich. 1982) (rejecting a father's attempt to secure his children's addresses from the Social Security Administration where father asserted that he consented on behalf of his children to release the addresses, noting that "[p]laintiff seeks his children's address for his own use, while his children seek no information from the Social Security Administration"). 
The justification for allowing the state to intervene in the home and usurp parental autonomy to enforce a clearly defined public policy is at its strongest in this situation, ${ }^{135}$ suggesting that courts should require proof of adherence to Title III's procedural requirements in all situations. This would require determining whether or not the child "consented" to interception in the first place.

The attempt to arrive at such a determination could be a journey into the ridiculous. If courts applied the standard they use to decide business cases to parental wiretapping, parents might be asked to show that their child was informed, in writing, that her calls were being monitored, and that the child knew or should have known that specific personal calls were overheard. Furthermore, it is doubtful that a finding of consent would have any meaning given the unequal balance of authority between children and their parents. ${ }^{136}$ To top it off, sociologists and psychologists have

135 Goldstein, Freud, and Solnit argue, for example, that there are two distinct responses to the question, "What should justify substituting the state's judgment for that of parents with regard to the care of a particular child? ${ }^{n}$ The first has been to set relatively precise limits on parental judgment concerning matters about which there is a clear societal consensus. For example, parents are not free to send their children into the labor market or to refuse to let them attend school or be immunized against certain contagious diseases. Legislative enactments like those concerned with child labor, compulsory education, and immunization are infringements upon parental autonomy which give parents fair warning of what constitutes a breach of their child care responsibilities and provide advance notice of the extent of the state's power to intervene. In thus defining the authority to intrude in precise terms, legislatures also restrict the power of administrative agencies and courts to breach the state's general commitment to family privacy and parental autonomy.

GOLDSTEIN ET AL., supra note 130, at 15-16 (footnote omitted). The second response, which is the focus of the book, requires judges and state agencies to act as "parens patriae with almost limitless discretion in areas generally under the exclusive control of parents." Id. at 17. Subjects of the second response include child neglect, custody disputes, and situations involving placement of the child away from parents.

An example of a situation where child/parent conflict may provide a justification for usurping parental authority is in the debate over abortions for minors. When a parent refuses to give permission to allow a minor child to have an abortion, the parent and child are deemed to be in such a "fundamental[ ] ... conflict" that notions of "safeguarding . . the family unit and of parental authority" are unlikely to be persuasive. Planned Parenthood v. Danforth, 428 U.S. 52, 75 (1976). Although the wiretapping issue may not rise to the fundamental level presented by abortion, conflicts over privacy may have profound effects on the family relationship and on parental control. This could lead to problems far greater than those claimed to justify the original eavesdropping.

136 A child can do little but agree to consent as required by their parent, due to the "inherent inequality between adult and child." GoLDSTEIN ET AL., supra note 130, at $13 \&$ n.17. "Consent" in this sense is not meaningful in terms of ensuring that the 
expressed concern about children's capacity to consent where the child is forced to assume a decision-making role. ${ }^{137}$

Alternatively, one could argue that the consent standard as applied through Title III to children does not really require a finding of "consent" in the strict sense of the word. There is a substantive difference between the demands made on children in the "hard cases" and those made on children in the Title III sense. Decisions concerning abortion, medical treatment, juvenile delinquency, educational choices, and other "hard cases," require children to act as though they were adults in deciding how to order their lives. ${ }^{138}$ The consent requirement of Title III does not require such highly developed decision-making skills-it is perhaps better thought of as a notice requirement which demands that children be informed of the wiretapping and understand the effect the wiretap will have on their privacy. ${ }^{139}$ In dealing with adult

child understands what they are giving up.

${ }^{137}$ See Gary B. Melton, Decision Making by Children, in ChILdREN's CoMPETENCE TO CONSENT 21, 32 \& n.15 (Gary B. Melton et al. eds., 1983) (discussing the harmful consequences of children making bad decisions related to privacy concerns); Maxine Wolfe, Childhood and Privacy, in 3 HUMAN BEHAVIOR AND ENVIRONMENT: ADVANCES IN THEORY AND RESEARCH 175, 216 (Irwin Altman \& Joachim F. Wohlwill eds., 1978) discussing the relationship between autonomy and the child's ability to make choices); Lloyd L. Weinreb, Generalities of the Fourth Amendment, 42 U. CHI. L. REV. 47, 60 (1979) (considering the capacity of a child to consent in the context of consenting to Fourth Amendment searches).

138 See generally CHILDREN's COMPETENCE TO CONSENT, supra note 137 (addressing issues surrounding children's capacity to engage in the complex decision making required to consent to medical treatment, psychotherapy, delinquency proceedings, and the like). Perhaps Justice Douglas's appreciation of the child's ability to make difficult choices prompted his dissent in Wisconsin v. Yoder, 406 U.S. 205 (1972), where he argued that:

It is the future of the student, not the future of the parents, that is imperiled by today's decision. If a parent keeps his child out of school beyond the grade school, then the child will be forever barred from entry into the new and amazing world of diversity that we have today. The child may decide that that is the preferred course, or he may rebel. It is the student's judgment, not his parents', that is essential if we are to give full meaning to what we have said about the Bill of Rights and of the right of students to be masters of their own destiny. If he is harnessed to the Amish way of life by those in authority over him and if his education is truncated, his entire life may be stunted and deformed. The child, therefore, should be given an opportunity to be heard before the State gives the exemption which we honor today.

Id. at 245-46 (Douglas, J., dissenting in part) (footnote omitted).

${ }^{139}$ Koocher suggests that it may be more appropriate to give children the power to "assent," or the power to veto, rather than the power to "consent," which implies a "reasoned and voluntary acquiescence." Koocher, supra note 129 , at 13. He argues 
victims of wiretapping, who have an individual capacity to grant or withhold consent to monitoring, the strict requirement of consent makes sense as a formal way of ensuring notice. For children in the home, however, formal notice requirements are impractable. Instead, the law might require the presence of conditions we associate with the "spirit" of consent.

At least one sociologist who studies the issue of children's capacity to consent has noted that research analyzing the management of access to children's private space "tells us something about day-to-day parent-child relations and also has some legal relevance. 140 According to Melton, such studies relate to the legality of searches and seizures under the Fourth Amendment, "particularly concerning the issue of the breadth of [the] reasonable expectation of privacy." 141 This provokes the question: "Under what circumstances do youngsters in fact have a reasonable expectation of privacy?"142 This suggests that consent implicates and affects the Katz-based "expectations" analysis proposed above. ${ }^{143}$ In sociological terms, the reasonable expectations of privacy and capacity to consent have been described as the existence and degree of a child's "control/choice" in the family. ${ }^{144}$ Control/choice is a variable element in a system of privacy which consists of two elements: privacy as interaction management, involving choices about how, where, and when to interact with others; and (more importantly for purposes of Title III) privacy as information management, which "relates to the individual's desire to manage past and present information about him/herself." ${ }^{145}$ Not surprisingly, the degree of control/choice we expect and need increases as we grow, rising from a complete lack of control/choice as infants (where adults control our interactions) to a high level of control choice as adolescents and young adults. ${ }^{146} \mathrm{~A}$ child's development can be

that "little risk is accrued by permitting minors to make [routine] decisions on their own, while there may be substantial benefit." Id.

140 Melton, supra note 137 , at 32.

141 Id. at 32 n.15; see also Weinreb, supra note 137, at 60 (addressing children's capacity to consent to Fourth Amendment searches).

142 Melton, supra note 137 , at 32 n.15.

143 See supra notes 89-112 and accompanying text.

144 See Wolfe, supra note 137 , at 180.

145 Id. at 178.

${ }^{146}$ See id. at 183-90. Wolfe engages in a "brief trip through childhood and adolescence, attempting to point out the privacy-related aspects of children's lives." Id. at 184. This description is quite illuminating as a basis for determining the reasonable expectations of privacy of various age groups. 
negatively affected when her degree of control/choice in managing information lags behind her increasing need for it. ${ }^{147}$

As applied to Title III, the control/choice indicators reflect the serious need for some form of consent to invasions of privacy, while at the same time suggesting a reasonable level of consent required in different situations by different children. At the same time, the control/choice standard requires much less than a strict finding of "consent." This provides a flexibility that is similar to the reasonable expectation of privacy standard as applied to the ordinary course of business. Indeed, it would seem that the ordinary course of business standard and the consent requirement are linked by this commonality. ${ }^{148}$ In order to conform to the spirit of Title III, which regards nearly all instances of nonconsensual wiretapping illegal, parents simply need to ensure that their children understand that their phone conversations can or will be monitored or recorded. ${ }^{149}$ This requirement may very well ruin parents' surreptitious attempts to catch their children doing what their parents do not want them to do; yet informing children of the possibility that they will be caught may be more effective at stopping those "wrongful" actions than surreptitiously invading their privacy, and implicitly, their trust.

\section{The Judicial TREATMENT OF DOMESTiC WiRETAPPING AT a CRossroads}

The debate among the courts as to whether Title III applies to domestic wiretapping has been characterized by a rather large philosophical split. Although the judicial history of interspousal wiretapping has been well documented over the past fifteen to twenty years, ${ }^{150}$ with the balance of decisions firmly in favor of holding Title III applicable to interspousal wiretapping, the courts

147 See id. at 215. 'Children's and adolescents' descriptions of information management experiences involve the attempts of others to lessen their autonomy, i.e., experiences with the loss of control over information which have negative consequences for the child or adolescent. With age, unsuccessful information management experiences (invasions) become increasingly associated with 'deviant' behavior." Id.

148 This link is implicitly reflected in many of the business wiretapping cases, where courts often use the existence of express or implied consent to determine whether the employee had a reasonable expectation of privacy relative to the normal business operations of the employer. See supra notes 75-76 and accompanying text.

${ }^{149}$ Of course, no monitoring is better than informed monitoring, but at least informed monitoring complies with Title III.

${ }^{150}$ See supra notes $20-21$ and accompanying text. 
have reached a crossroads at which they must decide whether to apply Title III to a wider class of cases, including, most notably, parental wiretapping. It is, therefore, helpful to discuss briefly the history of interspousal wiretapping cases before hypothesizing whether the philosophical split has or will continue to plague Title III analysis in the parental area.

\section{A. A Brief History: The Split Between Simpson and United States v. Jones}

The interspousal exception to Title III was created in 1974 by Simpson $v$. Simpson, ${ }^{151}$ which held that the statute did not apply to domestic conflicts, despite the fact that "[t]he naked language of Title III, by virtue of its inclusiveness" was applicable to the case. ${ }^{152}$ The court found that "Congress has not, in the statute, committee reports, legislative hearings, or reported debates indicated either its positive intent to reach [domestic wiretapping] or an awareness that it might be doing so."153 After citing the relative paucity of congressional statements regarding private electronic surveillance, the Simpson court found two other factors "important": the extension phone exception, and the fact that the defendant in the case-a man who intercepted and recorded the "mildly compromising" conversations of his wife with another man ${ }^{154}$-would be held criminally liable if the court found that Title III applied to the case. ${ }^{155}$ On this basis, the court "concluded that the statute is not sufficiently definite and specific to create a federal cause of action for the redress of appellant's grievances against her former husband." 156

Although the Simpson court was "not without doubts about [its] decision," and though the decision was limited to the facts of the case, ${ }^{157}$ a number of decisions have relied on and extended Simpson's holding. ${ }^{158}$ Anonymous $v$. Anonymous ${ }^{159}$ is typical both

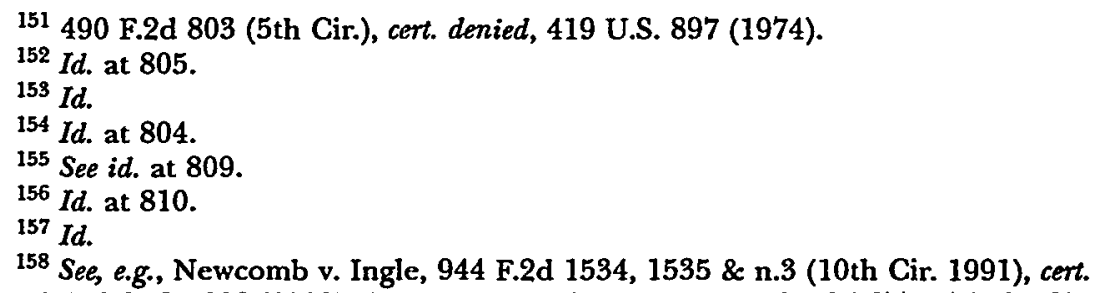
denied, 112 S. Ct. 903 (1992); Anonymous v. Anonymous, 558 F.2d 677, 679 (2d Cir. 1977); Perfit v. Perfit, 693 F. Supp. 851, 854-56 (C.D. Cal. 1988); Lizza v. Lizza, 631 F. Supp. 529, 532-33 (E.D.N.Y. 1986). 
of cases which follow Simpson and of cases which involve parental wiretapping. ${ }^{160}$ The defendant in Anonymous used the record feature of an answering machine to intercept and record conversations between his ex-wife and their daughter. ${ }^{161}$ Adopting the reasoning and statutory analysis of Simpson, the Anonymous court held that " $[t]$ he facts ... present a purely domestic conflict-a dispute between a wife and her ex-husband over the custody of their children-a matter clearly to be handled by the state courts." 162 Anonymous also relied on the extension phone exception: "[W]e, like Professor Schwartz, assume that 'nobody wants to make it a crime' for a father to listen in on conversations between his wife and his eight year old daughter, from his own phone, in his own home." ${ }^{163}$ The court reached this conclusion despite the fact that the father both recorded the conversations ${ }^{164}$ and was under a court order to leave the room when his daughter was speaking to her mother on the telephone. ${ }^{165}$ The Anonymous court did, however, narrow the holding in Simpson somewhat by distinguishing the situation at hand from one where all incoming and outgoing calls are recorded, thereby "invad[ing] the privacy of innumerable persons, known and unknown."166

159558 F.2d 677 (2d Cir. 1977).

160 Two other cases which follow Simpson involve parental wiretapping: one has been reversed. See Platt v. Platt, 685 F. Supp. 208, $209-10$ (E.D. Mo. 1988) (applying Anonymous and Simpson where a mother taped conversations between her husband and their daughter), rev'd, 951 F.2d 159 (8th Cir. 1989) (rejecting the district court's reliance on Simpson and Anonymous, and remanding for a determination of the nature of parent's recordings); Janecka v. Franklin, 684 F.Supp. 24, 26-27 (S.D.N.Y. 1987) (concerning a father who had taped conversations between his former wife and their children), affd, 843 F.2d 110 (2d Cir. 1988). It is interesting to note that the Janecka court came "exceedingly close" to imposing Rule 11 sanctions on the plaintiffs, but did not because "plaintiffs may have sincerely believed that the Court would seek to limit the scope of Anonymous." Id. at 27. Janecka was decided in the Second Circuit; therefore, the court was bound by the decision in Anonymous.

161 Anonymous, 558 F.2d at 678.

162 Id. at 679.

${ }^{163} \mathrm{Id}$. For a discussion of why this statement is misused, see supra notes 80-87 and accompanying text.

164 The court held that " $[t]$ he fact that appellee here taped the conversations which he permissibly overheard . . . [is] a distinction without a difference." Id. (citing Simpson, 490 F.2d at 809). The "difference" may be that recordings move the interception away from a simple inadvertent overhearing via extension phone and toward the realm of a more systematic invasion of privacy. See supra part I.A.

${ }^{165}$ Anonymous, 558 F.2d at 678 n.3. The spirit, if not the letter, of the court order to stay out of the room was, of course, abrogated to a degree by the defendant's tape recordings.

${ }^{166}$ Id. at 679. The plain language of Title III, of course, makes no such 
The first departure from the analysis in Simpson came two years later in a Sixth Circuit case, United States $v$. Jones. ${ }^{167}$ Reviewing the same legislative materials, the Sixth Circuit found the holding in Simpson "untenable because it contradicts both the explicit language of the statute and the clear intent of Congress expressed in the Act's legislative history." 168 The court found it "clear ... that the Congress enacted Title III to protect the privacy of all persons conversing over the telephone and that their privacy is shielded from invasion by third parties and spouses alike. ${ }^{n 169}$ Numerous courts followed on the heels of Jones, rejecting Simpson's analysis of Title III and the application of the interspousal immunity doctrine to wiretapping. ${ }^{170}$

The most caustic of the attacks on Simpson, exemplary (in all but its excess) of the recent trend among courts, comes from Kratz $v$. Kratz. ${ }^{171}$ Lowell Kratz, suspicious that his wife Mildred was having an affair, had a recording device installed on the telephone in his home. ${ }^{172}$ When Mildred brought an action under Title III for the interception of her calls, Lowell relied on Simpson to claim that the lack of congressional intent to include interspousal wiretapping in Title III precluded liability. ${ }^{173}$ Chief Judge Lord of the Eastern District of Pennsylvania began his analysis of Lowell's arguments with the observation that: "We would summarily dismiss such a fallacious approach to statutory interpretation had it not been the one adopted by the Fifth Circuit Court of Appeals in Simpson v. Simpson." 174 Pointing out that it "is difficult to imagine a statutory prohibition more 'definite and specific' than that of [Title III]," 175 Judge Lord criticized "then-Judge (and now former Attorney General) Bell" for his "most unusual and improper method of statutory analysis... [in] creat[ing], of his own accord, an exception to Title III not found in the statute, and ... in flagrant disregard of 18 U.S.C. $\$ 2511(1)$, which states that all exceptions to

distinction-it prohibits any interception by any person, and allows any aggrieved person to bring suit. See supra note 34 and accompanying text.

167542 F.2d 661 (6th Cir. 1976).

168 Id. at 667.

169 Id. at 670.

170 See supra note 20.

171477 F. Supp. 463 (E.D. Pa. 1979).

172 Id. at $465-66$.

173 Id. at 467.

174 Id.

175 Id. at 468 (quoting Simpson, 490 F.2d at 810). 
Title III have been provided specifically in the statute."176 "[I]gnoring traditional principles of statutory interpretation, ${ }^{n 177}$ Judge Lord continued, "the Simpson court engaged in judicial legislation by reading the plain words of Title III ("any person") to mean something other than what they said. But judges are not legislators, and this Humpty-Dumpty method of jurisprudence has no place in our constitutional system."178 Needless to say (but six pages later ${ }^{179}$ ) Judge Lord concluded that Simpson was wrong and that no interspousal exception to Title III exists. ${ }^{180}$

\section{B. A Classic Distinction Without a Difference}

Though the vast majority of courts have rejected Simpson in favor of Jones as applied to interspousal wiretapping, courts have been less willing to follow Jones where the aggrieved person is not an adult, but a child whose privacy has been violated. This trend is exemplified best by two recent decisions in the Tenth Circuit: Heggy v. Heggy ${ }^{181}$ and Newcomb v. Ingle, ${ }^{182}$ handed down a little over a month from each other and printed back-to-back in the reporter.

Heggy is typical of cases which follow United States $v$. Jones. Tom Heggy placed a voice-activated tape recorder on an extension telephone located in a barn next to his home in order to record the conversations of his wife whom he was in the process of divorcing. ${ }^{183}$ The court felt it was "compelled first and foremost by the clear and unambiguous language of the statute" to conclude that Title III applies to interspousal wiretapping. ${ }^{184}$ Referring to Title III's prohibition on the interception of communications "by any person except as specifically provided in the statute," the court found

176 Id.

177 Id.

${ }^{178} I d$. at $469-70$ (citation to Lewis Carroll omitted).

179 In the remaining pages, the words "untenable," "misread," "illogical," "backhanded," and "vague," among others, were used to describe Judge Bell's opinion. Id. passim.

${ }^{180}$ See id. at 476 . Judge Lord also summarily rejected reliance on Mildred's expectation of privacy, the existence of an extension phone exception, the applicability of the doctrine of interspousal immunity, Lowell's assertions that Title III was not a valid exercise of the Commerce Clause or that it violated Due Process, and the applicability of the domestic relations exception to federal jurisdiction. See id. at $472-76$.

181944 F.2d 1537 (10th Cir. 1991), cert denied, 112 S. Ct. 1514 (1992).

182944 F.2d 1534 (10th Cir. 1991), cert denied, 112 S. Ct. 903 (1992).

183 See Heggy, 944 F.2d at 1538.

181 Id. at 1539. 
the statute "clear on its face, [making] resort to legislative history ... seem unnecessary." 185 Even so, the court addressed Simpson head on, stating:

We reject not only the Simpson court's method of statutory analysis but also its interpretation of the legislative history. Instead, we agree with the district court [below] that the legislative history of Title III evinces a congressional awareness of the widespread use of electronic eavesdropping in domestic relations cases and an intent to prohibit such eavesdropping. ${ }^{186}$

The court finally

reject[ed the] contention that interpreting Title III to reach interspousal wiretapping results in unwarranted federal intrusion into the law of domestic relations, a subject traditionally left to state regulation. . . . It is highly unlikely . . . that applying Title III to interspousal wiretapping will result in increased federal regulation of domestic relations. Rather, the more likely result is a decrease in interspousal wiretapping. ${ }^{187}$

The language of Heggy stands in sharp contrast to the analysis of another panel of the Tenth Circuit in Newcomb $v$. Ingle. ${ }^{188}$ Newcomb's custodial parent intercepted and recorded telephone conversations between her minor son Brent and her ex-husband within her own home. ${ }^{189}$ In one of the recorded conversations, Brent's father could be heard instructing Brent as he set fire to his mother's home. ${ }^{190}$ Brent's mother turned the tapes over to Ingle, an assistant county attorney, who prosecuted both father and son. ${ }^{191}$ When Brent reached majority he filed suit against Ingle, his mother, and his grandfather (who had helped his mother install the recording device) alleging, among other things, a violation of Title III. ${ }^{192}$

Though the Newcomb court analogized the case to one "where spouses have tapped one another," the court pointed out, without elaborating, that it "is still qualitatively different from a custodial parent tapping a minor child's conversations within the family home. ${ }^{193}$ The court held that Title III did not apply

${ }^{185} \mathrm{Id}$. at 1540 (emphasis in original).

${ }^{186} \mathrm{Id}$. (footnote omitted).

187 Id. at 1541 (citation and footnote omitted).

188944 F.2d 1534 (10th Cir. 1991), cert denied, 112 S. Ct. 903 (1992).

189 See id. at 1535.

190 See id.

191 See $i d$.

192 See id.

${ }^{193}$ Id. at $1535-36$ (footnote omitted). 
because an interception via extension phone is "arguably permitted by a broad reading of the [extension phone] exemption."194 The court could find "no persuasive reason why Congress would exempt a business extension and not one in the home. The difference between listening on the extension and tapping the line within the home in the context here is not material. ${ }^{\text {195 }}$ Finally, the court quoted Simpson for the proposition that the extension phone exception showed Congress's intention to avoid "deciding a very intimate question of familial relations, that of the extent of privacy family members may expect within the home vis-a-vis each other." $\$ 196$

The distinction drawn between Newcomb and Heggy is quite perplexing. ${ }^{197}$ Although Heggy made two references to Newcomb, neither in any way explains the difference. ${ }^{198}$ The result in Newcomb may very well have been different had Brent's father sued rather than Brent: indeed, the Tenth Circuit subsequently allowed such a suit in another case. ${ }^{199}$ This may lead to the anomalous result that two parties to the same illegally intercepted conversation

194 Id. at 1536.

195 Id.

196 Id. (quoting Simpson, 490 F.2d at 809). The court also referred to Professor Schwartz's now infamous "I take it nobody wants to make it a crime" statement made during the debates on Title III. See id. at $1536 \mathrm{n} .5$; see also supra notes 80-87 and accompanying text.

197 See, e.g., People v. Otto, 831 P.2d 1178, 1188 n.10 (Cal.) (noting the lack of a "principled distinction" between the two cases), cert. denied, 113 S. Ct. 414 (1992); Richard I. Zuber, Domestic Eavesdropping and Wiretapping: Admissibility of Intercepted Communications, 22 CoLO. LAW. 455, 456 (1992) (observing that "there appear to be philosophical differences between the Newcomb and Heggy decisions").

${ }^{198}$ In footnote one, the Heggy court cited, without elaborating, Newcomb's statement that the parental wiretapping situation was "qualitatively different" from interspousal wiretapping. Heggy, 944 F.2d at $1538 \mathrm{n} .1$ (quoting Newcomb, 944 F.2d at 1535). In another footnote in the decision, the Heggy court asserted that its rejection of Simpson's "method of statutory analysis [and] interpretation of the legislative history" was "distinguishable from this court's previous citation to Simpson with approval in [Newcomb]" because Newcomb cited Professor Schwartz's comment to support Simpson. Id. at 1540 \& n.7. Of course, if Simpson's analysis of the legislative history of Title III was generally flawed, then its analysis of Professor Schwartz's statement was probably equally flawed.

199 See Thompson v. Dulaney, 970 F.2d 744 (10th Cir. 1992). The case involved one parent recording the conversations of her children with her separated husband during the course of a divorce. See id. at 746. The panel, which included one of the judges who decided Newcomb, "distinguish[ed] Newcomb as did Heggy by noting that in Newcomb it was a minor child living at home at the time of the wiretap who was complaining, whereas here, as in Heggy, it is the spouse who is complaining." Id. at 747 n.4. The court held that the interception could be a violation of Title III. See id. at 748-49 (remanding to the district court for final determination). 
will have different outcomes based solely on their relationship with the party intercepting the conversation. ${ }^{200} \mathrm{~A}$ more principled approach to the problem would have involved an analysis of whether the ordinary course of business exception applied to the circumstances in Newcomb. To use the court's own terminology, there is no persuasive reason to distinguish between the use of extension phones in businesses and in the home.

Evidently, only one court has pursued the "ordinary course of business" analysis in a parental wiretapping situation. In State $v$. Shaw, ${ }^{201}$ a North Carolina court considered a case in which a mother recorded the conversation of her son and "another young man," Shaw, over an extension phone. ${ }^{202}$ The tape, which the mother turned over to police, disclosed plans on the part of the men to buy some "shrooms" (psychedelic mushrooms). ${ }^{203}$ Based on this evidence, the police obtained a warrant to search Shaw's residence for controlled substances, which they found. ${ }^{204}$ Shaw was then arrested. The court relied on Rickenbaker $v$. Rickenbaker, ${ }^{205}$ in which the Supreme Court of North Carolina rejected the interspousal exception to Title III, and ruled the evidence against Shaw inadmissible. ${ }^{206}$ In discussing the extension phone exception, the court stated that " $[t]$ here was no evidence before the trial court that the mother used a microcassette recorder 'in the ordinary course of business." ${ }^{207}$ The court concluded "that the activity by the mother is prohibited by Title III, which states that any exceptions to its prohibitions are 'specifically provided for in this chapter." 208 Although the aggrieved party in State $v$. Shaw did not reside within the home (he was on the other end of the line), the application of the court's analysis seems equally

200 As Judge Pollack noted in London v. London, 420 F. Supp. 944 (S.D.N.Y. 1976), aff', Anonymous v. Anonymous, 558 F.2d 677 (2d Cir. 1977):

Having read the statute as not extending to the interception of calls by family members within the family home, it would be anomalous to conclude that although 18 U.S.C. $\$ 2520$ confers no cause of action in favor of the family member it does confer a claim on the other party to the call.

Id. at 947.

201404 S.E.2d 887 (N.C. Ct. App.), appeal denied, 407 S.E.2d 548 (1991).

202 Id. at 888.

203 See id.

204 See id.

205226 S.E.2d 347 (N.C. 1976).

206 See Shaw, 404 S.E.2d at 889.

207 Id. (quoting 18 U.S.C. $\$ 2510(5)(a)(i)$ ).

${ }^{208} I d$. (quoting $\$ 2511(1)$ ). 
applicable had the mother's son pursued the claim, unless of course the court suddenly decided to read a parental immunity exception into Title III. Nevertheless, State $v$. Shaw represents a substantial step toward applying Title III to parental wiretapping.

Title III jurisprudence is now at a crossroads. Courts must decide whether to continue the trend of applying Title III to domestic wiretapping situations or to balk at the brink of prohibiting private wiretaps entirely. The mandate of Title III is clear; in essence it says "read my lips: no private wiretaps." Nevertheless, the courts have been squeamish about their decisions in cases both where Title III is interpreted to include an interspousal exemption and cases where it is not. ${ }^{209}$

What we have, to this point, is a relatively clear statute that is broad enough to encompass parental wiretapping; an interpretation of the exceptions to that statute which allows enough flexibility to fit the vagaries of children's needs while maintaining a sufficient degree of rigor; and a case history which leaves open the possibility of further judicial action. What is still needed is a justification and strategy for action.

\section{The JUSTIFICATION AND STRATEgY FOR APPLYING TITLE III TO PARENTAL WIRETAPPING}

The relationship between parent and child is one which requires particular delicacy. ${ }^{210} \mathrm{It}$, even more than the relationship be-

${ }^{209}$ See, e.g., Lizza v. Lizza, 631 F. Supp. 529 (E.D.N.Y. 1986):

The Act is a far-reaching one which, if read to cover circumstances such as that presented by the instant case, would have serious ramifications as to the degree of federal control over actions by family members within their own homes. Absent a signal, either in the statute itself or in the legislative history, that Congress intended that the Act's criminal and civil proscriptions and liabilities to extend to a decision by a spouse to record conversations on his own residence's telephone, this Court must decline to impute such an intent.

Id. at 533 .

The Lizza court's concern is common to courts considering issues of familial wiretapping. See also United States v. Jones, 542 F.2d 661, 673 (6th Cir. 1976) ("We reach this conclusion [that interspousal wiretapping is prohibited by Title III] reluctantly because we share the concern of other courts which have grappled with this problem that application of federal wiretap law to essentially domestic conflicts may lead to harsh results in individual cases.").

210 See Rodham, supra note 131, at 487 ("The[] issues of family autonomy and privacy, state responsibility, and children's independence are complex, but they determine how children are treated by the nation's legislatures, courts, and administrative agencies."). 
tween husband and wife, is the basic element of society. A primary concern of the law, then, must be to protect the proper functioning of that relationship. In doing so, the law often dictates how some of the most intimate social relationships are ordered. From the moment of birth the law steps in to ensure that the child's "best interests" are being served. ${ }^{211}$ Not everyone is comfortable with the extensive and increasing role of the law in family life, but for very different reasons. On one side, traditionalists argue that the quasi-constitutional rights of parental autonomy and familial privacy are degraded when the government intrudes on the parent-child relationship. On the other side, children's rights advocates insist that children can and should decide what is best for themselves. Somewhere in between lies the justification for granting or denying children the statutory protection of Title III. ${ }^{212}$

It is generally accepted that a lack of privacy is detrimental to the development of children. ${ }^{213}$ On the other hand, it is also accepted that state intervention in family life, though sometimes

\section{(1979): \\ The degree of state intervention on the private ordering of the parent-child relationship ranges from a minimum-automatic assignment of a child by birth certificate to his biological parents-to a maximum-court-ordered removal of a child from his custodians because he is found to be "neglected" or "delinquent" or they are "unfit" to be parents. The traditional goal of such interventions is to serve "the best interests of the child."}

211 See JOSEPH Goldstein ET AL., BEyond the Best INTERESTS OF THE CHILD 4

Id.

212 It seems obvious that those who favor the children's rights viewpoint would support the extension of Title III's protections to children. The corollary assumption is that those who favor parental autonomy would oppose the application of Title III to children on the theory that it would interfere with domestic relations. It should be stressed, however, that although this section focuses on the constitutional and quasi-constitutional bases for applying Title III, Title III itself does not rest on constitutional principles beyond the simple application of the Commerce Clause power to the use of telephones in interstate commerce. The "rights" conferred by Title III can therefore be applied independently of this analysis, though the justification for applying it may depend on a particular court's philosophical stance.

218 In summarizing research by psychologists on the effects of privacy on children, one book noted that

access to privacy for children was generally found to be connected to self esteem, the production of positive social behavior, and allowing the child to separate from others in order to individuate and become more self-reliant. All of these findings serve as examples of adaptive behavior designed to optimize one's relationship with the home and, subsequently, with the world outside.

1 HANDBOOK OF ENVIRONMENTAL PSYCHOLOGY 661 (Daniel Stokols \& Irwin Altman eds., 1987) (citations omitted); see also supra notes $140-47$ and accompanying text. 
justified, can be detrimental to a child's development. ${ }^{214}$ Historically, one way the law sought to protect the privacy of familial relations was to deny causes of action by one family member against another through the doctrines of interspousal and parental immunity. ${ }^{215}$ The major justification for both types of immunity is that it "promotes family harmony" by encouraging the private settlement of familial disputes. Like the interspousal immunity doctrine, however, which has been abrogated in a majority of states, ${ }^{216}$ parental immunity is generally a doctrine of the past. ${ }^{217}$ There are at least two explanations for this. First, denying access to courts does not necessarily promote family harmony. Indeed, in the case of wiretapping it is hard to see how family harmony is served by allowing family members to tap each other's phones. ${ }^{218}$ Second, the parental immunity doctrine has fallen

214 For example, Goldstein, in the context of state decisions regarding the placement of children, advocates a policy of "minimum state intervention" in the home. GoldSTEIN ET AL., supra note 130 , at 4. Goldstein argues that the

complex and vital developments [during childhood] require the privacy of family life under guardianship by parents who are autonomous. The younger the child, the greater is his need for them. When family integrity is broken or weakened by state intrusion, his needs are thwarted and his belief that his parents are omniscient and all-powerful is shaken prematurely. The effect on the child's developmental process is invariably detrimental.

Id. at 9. Nonetheless, Goldstein does acknowledge that state intervention is required in some cases:

Family privacy may become a cover for exploiting the inherent inequality between adult and child. It may prevent detection of the uncontrolled expression of both unconscious and conscious hatred some parents have for their children. Family privacy ceases to benefit the child and becomes a threat to his well-being, to his safety, and occasionally to his life. Those dangers justify state intervention.

Id. at 12-13 (footnote omitted).

215 See Rowe, supra note 21, at 863-67 (providing an historical overview of the common law and present day interspousal immunity doctrine).

${ }^{216}$ See Adena J. Adler, Note, 58 TEMP. L.Q. 709, 709 n.1 (1985) (listing the jurisdictions which have partially or totally eliminated the interspousal immunity doctrine).

217 See Foster, supra note 131, at 59.

218 See supra notes $132-35$ and accompanying text. Seéalso Burgess v. Burgess, 447 So. 2d 220 (Fla. 1984):

The policy of marital harmony is not furthered by permitting one covertly to invade the privacy of his or her spouse without fear of civil reprisal. It is undisputed that spying and prying by one spouse into the private telephone conversations of the other does not contribute to domestic tranquility or assist in preserving the marital estate. Eavesdropping, by nature, undermines the faith and trust upon which the institution of 
victim to an increasing recognition of children's rights.

Over the past thirty years, the Supreme Court has effectively eradicated the notion that children have no rights under the Constitution. ${ }^{219}$ In that same period, however, the quasi-constitutional rights to parental autonomy and freedom from state intrusion into the family have been increasing. ${ }^{220}$ As Goldstein points out, ${ }^{221}$ the Supreme Court has recognized "the integrity of [family] life [a]s something so fundamental that it has been found to draw to its protection the principles of more than one explicitly granted Constitutional right." 222 When the children's rights and

marriage is founded. A rule of law which leaves such repugnant behavior unsanctioned can hardly be said to preserve the marital unit.

Id. at 222-23; State v. Jock, 404 A.2d 518, 520 (Del. 1979) ("To recognize interspousal immunity in this context would reward the surreptitious spouse while according the privacy of the targeted spouse less protection than is provided for suspected criminals."). Though the courts in these cases were referring to the protection for interspousal wiretapping, their analysis is no less applicable to parental wiretapping.

${ }^{219}$ See In re Gault, 387 U.S. 1, 13 (1967) ("[W] hatever may be their precise impact, neither the Fourteenth Amendment nor the Bill of Rights is for adults alone."); Tinkerv. Des Moines Ind. Sch. Dist., 393 U.S. 503, 513-14 (1969) (affirming children's right to freedom of expression); Carey v. Population Servs. Int'l, 431 U.S. 678, 691700 (1977) (rejecting state ban on sale of contraceptives to children under 16); Planned Parenthood v. Danforth, 428 U.S. 52, $72-75$ (1976) (rejecting parental power to veto a child's abortion).

220 See Bellotti v. Baird, 443 U.S. 622, 642-44 (1979) (upholding a law requiring parental notification of a child's abortion); Wisconsin v. Yoder, 406 U.S. 205, 229-34 (1972) (upholding the right of Amish parents to keep their children out of public schools); Hodgson v. Minnesota, 497 U.S. 417, 444-49 (1990) (upholding parental consent requirement of an abortion statute). But see Robert A. Burt, The Constitution of the Family, 1979 SUP. CT. REV. 329, 351 ("Notwithstanding an occasional rhetorical flourish from spokesmen for both blocs, principled legitimacy for parental authority as such in preference to other sources of social power commands no adherents yet among liberal or conservative Justices of this generation."). Of course, this statement may not be applicable to the new generation of Justices currently on the Court.

The rights to parental autonomy and familial integrity are also supported by child psychologists. See, e.g., GOLDSTEIN ET AL., supra note 130, at 9-10 (discussing the importance of family integrity as it relates to child placement decisions by the state). Goldstein argues that family integrity consists of three elements: parental autonomy, a child's rights to autonomous parents, and privacy. See id. Preserving family integrity serves two purposes:

The first is to provide parents with the opportunity to meet the developing physical and emotional needs of their child so as to establish the familial bonds critical to every child's healthy growth and development. The second purpose, and the one on which the parental right must ultimately rest, is to safeguard the continuing maintenance of these family ties-of psychological parent-child relationships-once they have been established.

Id.

221 See GOLDSTEIN ET AL., supra note 130, at 9.

222 Poe v. Ullman, 367 U.S. 497, 551-52 (1961) (Harlan, J., dissenting); see also 
parental rights clash, as in Bellotti $v$. Baird, ${ }^{223}$ which pitted the constitutional right of minors to obtain an abortion against the quasi-constitutional rights of parental autonomy and family integrity, the issues become quite complex. ${ }^{224}$ It is not clear that it is possible or even desirable to raise the competing interests involved in parental wiretapping to this level of constitutional importance.

One way to avoid creating a constitutional debate over applying Title III to children is to couch the competing interests in terms of more traditional individual rights, rather than attempting to constitutionalize a right to familial autonomy in the context of wiretapping. Professor Laurence Tribe, for example, suggests that "family integrity" is simply a catch-all phrase describing a conglomeration of individual rights, and that, taken together, decisions concerning families and those concerning the individuals that make up families cancel each other out. ${ }^{225}$ He points out that decisions such as Wisconsin $v$. Yoder 226 and Planned Parenthood $v$. Danforth, 227 though facially at odds, "can be reconciled ... by observing which child-rearing strategies have won the Justices' respect," namely, only those in which "parents succeed (as the Court found that 'the Amish succeed') in bringing obedient social conformance from their children." 228 This theory may imply that the failure of Brent Newcomb's mother to keep her child from trying to burn down her home ${ }^{229}$ should bar her, theoretically at least, from exemption under Title III. A more principled way to address the Title III situation, however, would be to argue from a positive notion of children's rights under the statute, as suggested by various children's advocates.

A positive formulation of children's rights can be achieved at many different levels of generality. The most extreme, often associated with Hillary Rodham Clinton's early writings, ${ }^{230}$ con-

Griswold v. Connecticut, 381 U.S. 479, $499-500$ (1965) (Harlan, J., concurring).

${ }^{223} 443$ U.S. 622 (1979).

224 See TRIBE, supra note 129 , at 1590 n.8.

225 See id. at 1416; see also Burt, supra note 220, at 351 (noting the Court's failure to lend special deference to family authority).

${ }^{226} 406$ U.S. 205 (1972).

227428 U.S. 52 (1976).

228 TRIBE, supra note 129, at 1417.

229 See Newcomb v. Ingle, 944 F.2d 1534, 1535 (10th Cir. 1991).

230 See generally Rodham, supra note 131 (arguing for a revision of our present American "legal conception of children's status" and thereby give recognition to children's needs and concerns as legal rights). 


\section{tains three arguments:}

a) the legal status of infancy, or minority, should be abolished and the presumption of incompetency reversed; b) all procedural rights guaranteed to adults under the Constitution should be granted to children whenever the state or a third party moves against them, judicially or administratively; and c) the presumption of identity of interests between parents and their children should be rejected whenever the child has interests demonstrably independent of those of his parents (as determined by the consequences to both of the action in question), and a competent child should be permitted to assert his or her own interests. ${ }^{231}$

Under such a broad theoretical base, Title III would clearly apply to children. Realistically, however, the likelihood of Clinton's position being adopted is slight. Any such change would require a literal revolution in the law, such that even those who advocate broadening children's rights are critical of the extreme solution of granting full rights to children. For example, Robert Mnookin argues that "because children lack adult capacity and maturity, giving children the same rights and obligations as adults would often do them a substantial disservice. They may need special protection. ${ }^{\text {232 }}$

More fundamentally, invoking the arguments supporting the notion that children ought to be granted a full spectrum of rights in order to provide protection under Title III would seem to be overkill. What is needed is a more pedestrian justification for judicial action which requires little revolution in the law, yet avoids the pitfalls of full-blown state intervention in the home. ${ }^{233}$

231 Id. at 507.

232 ROBERT H. MNOOKIN, IN THE INTEREST OF ChILDREN: ADVOCACY, LAW Reform, AND PUBliC POLICY 31 (1985).

${ }^{233}$ Though parental wiretapping may be detrimental to children, see supra note 213 and accompanying text, the harm may neither rise to the same level as harms which normally justify state intervention, nor outweigh the harms caused by state intervention, see supra note 214 and accompanying text. The harms of parental wiretapping thus fall in a grey area where we would like to protect children's interests, but fear the dangers of intervention:

The courts have traditionally respected the sanctity of the family unit, and are quite reluctant to become involved without clear evidence of abuse, neglect, or similar dramatic turns of events. In the vast majority of situations, this is a very appropriate stance. Unfortunately, however, the threshold for intervention is often set beyond the level at which psychological problems are precipitated. That is to say, errors or decisions that are not in the child's best interests often do not come to the attention of the law or reach a level where legal intervention is possible, despite the fact that psychological harm may be occurring. 
strategy proposed by Mnookin for use by children's rights reformers may provide a middle ground which is quite appropriate for applying Title III to children: test case litigation. As Mnookin points out, litigation can often be more effective than legislation, especially in an area of law as controversial as children's rights. ${ }^{234}$ He lists three specific advantages to litigation. First, by virtue of their role, courts are required to listen to children's rights reformers. Second, courts appear to be more receptive to arguments based on principle, especially when offered for those traditionally deprived of legal recourse. Finally, when compared to lobbying, litigation engenders relatively few political and ethical problems. ${ }^{235}$

Test case litigation may be the best way to enforce children's rights, ${ }^{236}$ especially under a law which has been so thoroughly debated in the courts. By announcing a more rigid prohibition on domestic wiretapping, courts will be able to recognize the harms being caused to children, reconcile the disparate treatment of parental wiretapping with the purposes of Title III, and avoid a serious invasion into the realm of familial autonomy. Although Title III litigation initiated by children against their parents may not, in those cases, improve familial harmony, it will, in the long run, deter instances of parental wiretapping by generating a recognition of children's rights under Title III among lawyers, judges, parents, social workers, and others in a position to make a difference. $^{237}$

Koocher, supra note 129 , at 14 . Because Title III already exists as a legislative pronouncement against private wiretapping, if courts simply enforce the law parents will be given fair warning that the parental wiretapping is a "breach of their child care responsibilities." See supra note 135.

234 See MNOOKIN, supra note 232, at 521-23.

235 See id. at 522.

236 See id.

237 This phenomenon has somewhat belatedly emerged in the context of interspousal wiretapping. See, e.g., Zuber, supra note 197, at 456. Zuber's colorful warning to practitioners of family law takes the form of poetry:

If a client with a tape likens it to Watergate,

If the lawyer is not leery of those secrets dark and dreary,

If he fails to be wary,

He may find a fate contrary, when the FBI comes knocking, knocking at his office door.

Id. at 458; see also Jan L. Warner \& C. Dixon Lee III, Federal Implications of Wiretapping and Other Electronic Surveillance in Family Law Cases, 1 AM. J. FAM. L. 159 (1987) ("The family law practitioner must be on guard against the overzealous client or opponent who utilized improper 'self help.' The family law practitioner must guard 


\section{CONCLUSION}

Title III's clear and unambiguous prohibition of nonconsensual private wiretapping should be applied to all instances of domestic wiretapping. The reluctance of courts to impose this restriction on the family is unjustified not only by the legislative history and case law, but in light of the deleterious effects wiretapping has on familial relations. Nonetheless, even with a theoretical justification for applying Title III to children and a strategy for doing so, public policy and sentiment may present a barrier to the application of Title III to parental wiretapping, ${ }^{238}$ due to the perception that enforcing the law against parents will only make matters worse. Indeed, in an age when children can successfully sue their parents for divorce, ${ }^{239}$ the last thing that is needed is another way to drive a wedge into the family. It is my hope, in proposing a justification for making all domestic wiretapping illegal, that it does not cause an increase in the federal regulation of domestic relations. Rather, I hope that the more likely result is a decrease in parental wiretapping. ${ }^{240}$ Allowing a few test cases may obviate the necessity of twenty years of debate in the courts. Perhaps in this way, we can avoid the endless flood of cases seen in the interspousal wiretapping dispute, which leaves in its wake a string of broken homes.

against these perils and be prepared to defend his or her client when electronic intrusion occurs.").

${ }^{238}$ See, e.g., ELECTRONIC SURVEILLANCE, supra note 5, at 169-70. In discussing courts' general reluctance to enforce Title III against domestic wiretappers, a Justice Department attorney testified "[i]f you want to see a hostile court, ... imagine a prosecution of a father who is eavesdropping on his 19 year-old daughter who he is afraid has a drug habit." Id. In order to apply Title III on behalf of children, courts will have to overcome this hostility. Considering the squeamishness which still plagues decisions on interspousal wiretapping, see supra note 114 and accompanying text, judicial acceptance of liability for parental wiretapping may be a long time coming.

239 See, e.g., Kingsley v. Kingsley, Nos. 92-2430, 92-2446, 1993 Fla. App. LEXIS 8645 , at *1 (Fla. Dist. Ct. App. Aug. 18, 1993) (upholding a suit initiated by a child to terminate the parental status of his mother).

240 See Heggy v. Heggy, 944 F.2d 1537, 1541 (10th Cir. 1991) (expressing this desire in the context of interspousal wiretapping). 